\title{
Characterization of a Post Orogenic A-Type Granite, Gabal El Atawi, Central Eastern Desert, Egypt: Geochemical and Radioactive Perspectives
}

\author{
Khairiya M. Fawzy \\ Geology Department, Faculty of Science, Aswan University, Aswan, Egypt \\ Email: khairiyafawzy@yahoo.com
}

How to cite this paper: Fawzy, Kh.M. (2017) Characterization of a Post Orogenic A-Type Granite, Gabal El Atawi, Central Eastern Desert, Egypt: Geochemical and Radioactive Perspectives. Open Journal of Geology, 7, 93-117.

http://dx.doi.org/10.4236/ojg.2017.71007

Received: December 8, 2016

Accepted: January 22, 2017

Published: January 25, 2017

Copyright $\odot 2017$ by author and Scientific Research Publishing Inc. This work is licensed under the Creative Commons Attribution International License (CC BY 4.0).

http://creativecommons.org/licenses/by/4.0/

\begin{abstract}
The alkali feldspar granite of Gabal El Atawi is post orogenic granite originated from subalkaline magma in extensional suite. It is developed within plate tectonic setting and has $\mathrm{A}_{2}$-type character which generated from apparent crustal source. The petrographic, geochemical and radioactive characteristics of El Atawi granite meet and fulfill the requirements of being fertile granite and it can be considered as promising uraniferous granite. Fluid inclusion studies of the altered granite elucidated two different solutions acting on the host granitic pluton. The first is $\mathrm{NaCl}-\mathrm{CaCl}$ low temperature fluid with a wide range of salinity. The second is high temperature and salinity Fe-Mg-Na chloride solution. Different fractures in the granite acted as good channels for the hydrothermal fluids that leached uranium from its bearing minerals disseminated all over the host granite and redeposited it in the alteration zones.
\end{abstract}

\section{Keywords}

Radioactivity, Geochemistry, Post-Orogenic, A-Type Granite, Gabal El Atawi, Central Eastern Desert, Egypt

\section{Introduction}

In the Late Proterozoic Pan African Nubian Shield of Egypt, two types of granitoid rocks grouped as older assemblage referred to as grey or syn-to late-orogenic, calc-alkaline quartz-diorite to granodiorite (850 - 614 Ma) and younger (610 - 550 $\mathrm{Ma}$ ) post-orogenic monzogranite, syenogranite and alkali feldspar granite assemblage [1] [2].

The younger granites form about $16 \%$ of the basement outcrops in the Eastern 
Desert [3]. Hussein et al. [4] divided the Egyptian younger granites into suture related granites (G2-granite) formed in post-orogenic environment and intraplate granites (G3-granite) related to rifting processes. Hassan and Hashad [2] suggested that the magma of the younger granites was emplaced in three possible tectonic settings: (1) subduction processes in a volcanic arc environment, (2) arc-continent collision event and (3) within continental plates. Noweir et al. [5] considered the Egyptian younger granites as transitional phases from calc-alkaline I-type magmatism to normal alkaline and peralkaline A-type granite. EI-Sayed [6] classified the Egyptian granites into I-type orogenic arc related and A-type anorogenic rift-related granites. Some of the post-collisional A-type granite plutons in the ANS are considered as specialized granites [7] [8] [9]. They are characterized by a marked enrichment in granitophile trace elements and valuable metals of economic interest, like $\mathrm{Nb}, \mathrm{Ta}, \mathrm{Zr}, \mathrm{Th}, \mathrm{U}, \mathrm{Y}, \mathrm{Sn}$ and rare earth elements (REE).

Gabal El Atawi granitic pluton is located at the eastern part of the Central Eastern Desert between latitudes $25^{\circ} 32^{\prime} \mathrm{N}$ and $25^{\circ} 38^{\prime} \mathrm{N}$ and longitudes $34^{\circ} 6^{\prime} \mathrm{E}$ and $34^{\circ} 14^{\prime} \mathrm{E}$ (Figure 1). It is occurring $\approx 45 \mathrm{~km}$ to the west of Quseir-Marsa Alam asphaltic road. El Atawi granitic pluton is roughly oval shaped elongated in the ENE direction with $5 \times 9 \mathrm{~km}^{2}$ and dissected by Wadi El Miyah.

Several studies have been carried out on El Atawi area. $\mathrm{Rb} / \mathrm{Sr}$ isochron age of El Atawi granites is obtained $580 \mathrm{Ma}$ [10], $587 \pm 11 \mathrm{Ma}$ with ${ }^{87} \mathrm{Sr} /{ }^{86} \mathrm{Sr}$ initial ratio (0.7058) [11] and $587 \pm 27 \mathrm{Ma}$ [12]. Anomalous rare metals concentrations in Gabal El Atawi area are recorded by [13]. Yonan [14] and Fasfous et al. [15] studied the fluorite mineralization. Obeid [16] advocated El Atawi granitic pluton strongly differentiated rare metal (chemically specialized) granite. Sadek [17] mapped a detailed geologic map for Gabal El Atawi area. Salman [18] carried out geochemical prospecting studies for radioactive mineralization at G. El Atawi area. Fawzy [19] studied the genesis of fluorite veins cutting the western part of the pluton.

Khawasik [20] recorded uranium and thorium mineralizations near the northeastern contact of the granites with the metasediments. Attawiya [21] recorded Th-rich minerals (thorite, uranothorite, thorianite, thorogummite) and U-rich minerals (uraninite, delorenzite) and secondary minerals (uranope, soddyite) which are found staining the surfaces of joints and faults. Al Anwar [22] studied the geochemistry of the hydrothermally altered granites. The studied granites were obviously subjected to various alteration processes (hematitization, kaolinitization and fluortization). The alteration zones show the highest $\mathrm{U}$ and Th contents as a result of alteration processes. Though much data on geochemistry and general description of radioactivity and ore mineralogy of El Atawi granite are available, practically there is no information on the nature of the mineralizing fluids. Fluid inclusions trapped in minerals provide information on the physicochemical conditions attending various geologic processes including hydrothermal activity. In this view, an attempt has been made to identify the nature of mineralizing fluids and mineralization processes using fluid inclusion studies on 
the altered granite.

The present work aims to study the geochemical characteristics, petrogenesis and radioactivity of Gabal El Atawi granitic pluton and encompasses details of micro-inclusions data in altered granite samples to elucidate the genesis and evolution of the mineralizing fluids.

\section{Geologic Setting}

El Atawi area is covered, from oldest to youngest, by serpentinite and talccarbonates, metasediments, metavolcanics, older granites, Hammamat group, younger granites, post granite dykes, trachytes and veins. The serpentinite bodies show tectonic contact with the metasediments that trending NW and metavolcanics. The older granites occupy the northeastern sector of the area and comprise tonalite and granodiorite rocks of Gabal El Shosh. The Hamamat sediments unconformably overlie the metasediments and metavolcanics.

The younger granites occur as highly elevated lensoidal mass intruding the meta-sedimentary and metabasalts in the central part of mapped area. They display sharp intrusive contacts with the country rocks. The younger granites are traversed by a group of faults trending mainly NW and NE and crossed by several post granite basic, intermediate and acidic dykes exhibiting various lengths and thickness trending in the NW-SE and E-W directions. Quartz-fluorite-calcite veins trending $\mathrm{N}-\mathrm{S}$ and dipping $\approx 80^{\circ}$ to the east are cutting the western part of the younger granite mass (Figure 1 ).

The younger granites are homogeneous medium to coarse-grained with light pink color. In the northern border of the pluton, close to the contact with the metasedimentary rocks, the granites are altered. Alteration zones are commonly located in the apical portions of the investigated granite occurring as irregular patches forming the outer margin. Sometimes, they extend along the major ENE or NW trending fractures and faults over several meters across the structures. The hydrothermally altered granites are white in color, fine-grained and coated with Fe-oxides.

\section{Methodology}

A total of nine representative samples from the younger granite were chemically analyzed for major oxides, trace elements and REE. The XRF analysis was done on pressed powder after mixing the samples with the Mowiol II polyvinyl alcohol and pressed to pellets of $4 \mathrm{~cm}$ in diameter for measuring trace elements and the samples have been measured for major oxides after fusion with tetra borate melted pellets using the XRF Philips PW2400 X-ray fluorescence spectrometer. The detection limits are approx. $0.01 \%$ for MOs and 1 to $4 \mathrm{ppm}$ for TEs. The accuracy of the analyses was assessed by analysis of standard reference materials. The REEs were determined by inductively coupled plasma (ICP). The analyses were conducted at the Institute of Earth Sciences, Lausanne University, Switzerland. The results are given in Table 1, Table 2.

Representative samples from the alteration zones were chosen for fluid 


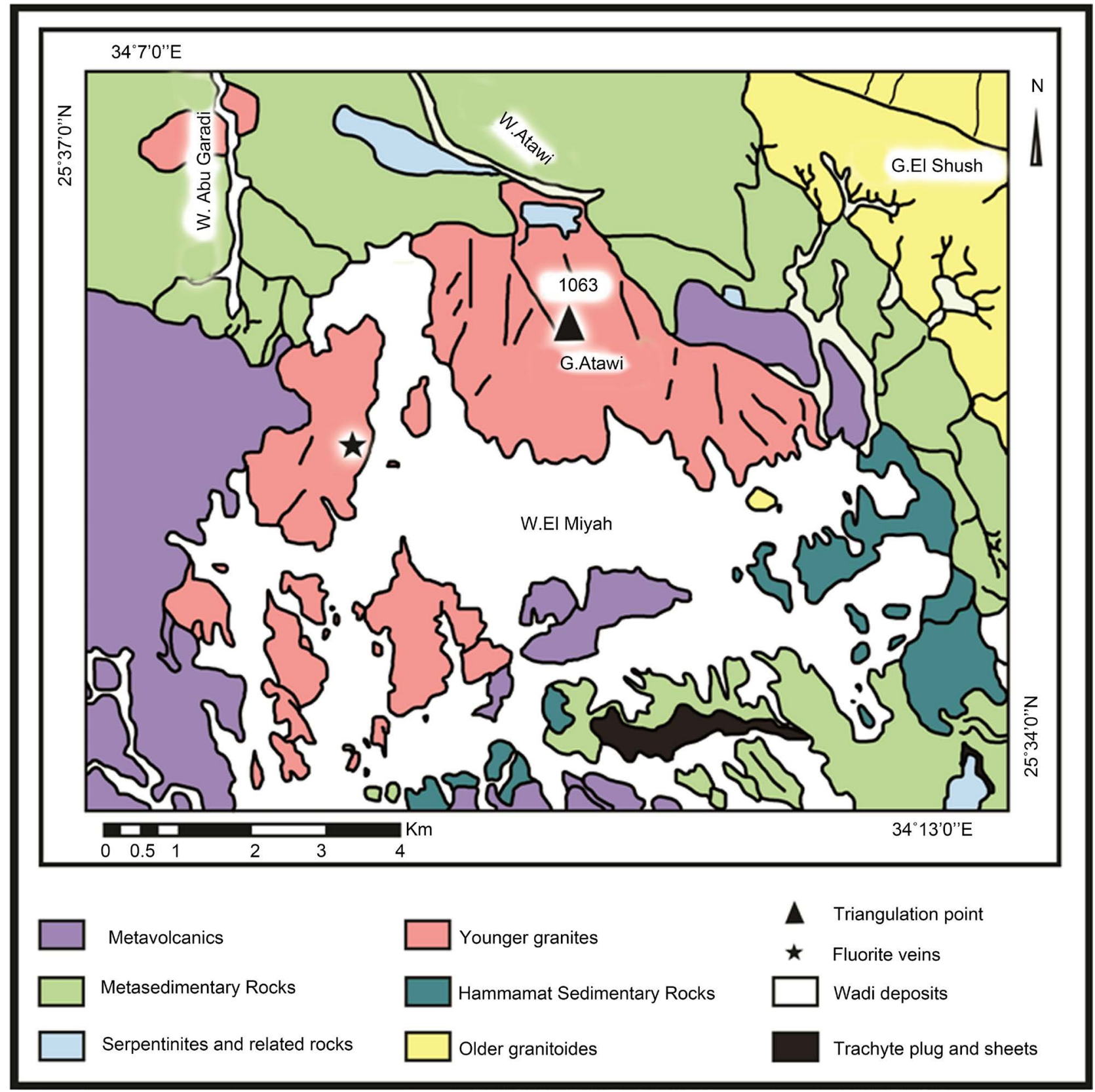

Figure 1. Geological map of Gabal El Atawi area (after [16]).

inclusion studies. The microthemometric measurements on inclusions in quartz from the schlieren (authigenic quartz formed during alteration) were carried out in order to estimate physico-chemical conditions of alteration. Microthermometric studies were conducted in Geology Department, Faculty of Science, Aswan University, Egypt using Linkam MDSG600 heating/freezing stages. Samples were cut into thin slabs using a diamond-edged saw with a slow speed to avoid overheating. From each slab a doubly polished wafers was produced using standard techniques. From microthermometric results the bulk composition of the fluids could be calculated using FLINCOR computer program [23] and the minimum conditions of trapping are estimated. 
Table 1. Major oxides (\%) and Trace elements (ppm) for Gabal El Atawi granites.

\begin{tabular}{|c|c|c|c|c|c|c|c|c|c|c|}
\hline Sample No. & 6 & 7 & 8 & 9 & 10 & 11 & 12 & 13 & 14 & Average \\
\hline $\mathrm{SiO}_{2}$ & 75.8 & 74.7 & 77.2 & 75.8 & 76.0 & 76.8 & 75.6 & 76.5 & 76.6 & 76.1 \\
\hline $\mathrm{TiO}_{2}$ & 0.05 & 0.24 & 0.04 & 0.1 & 0.08 & 0.07 & 0.09 & 0.03 & 0.08 & 0.09 \\
\hline $\mathrm{Al}_{2} \mathrm{O}_{3}$ & 12.3 & 12.1 & 12.0 & 12.5 & 12.2 & 12.2 & 12.2 & 12.3 & 12.3 & 12.2 \\
\hline $\mathrm{Fe}_{2} \mathrm{O}_{3}$ & 1.09 & 2.48 & 1.21 & 0.86 & 1.37 & 1.2 & 1.64 & 1.28 & 1.52 & 1.41 \\
\hline $\mathrm{MnO}$ & 0.02 & 0.05 & 0.02 & 0.01 & 0.01 & 0.02 & 0.01 & 0.03 & 0.02 & 0.02 \\
\hline $\mathrm{MgO}$ & 0.05 & 0.21 & 0.03 & 0.04 & 0.05 & 0.04 & 0.02 & 0.02 & 0.04 & 0.06 \\
\hline $\mathrm{CaO}$ & 0.45 & 0.82 & 0.32 & 0.64 & 0.37 & 0.76 & 0.55 & 0.18 & 0.35 & 0.49 \\
\hline $\mathrm{Na}_{2} \mathrm{O}$ & 4.5 & 3.87 & 4.32 & 4 & 3.92 & 3.92 & 4.06 & 4.56 & 4.13 & 4.14 \\
\hline $\mathrm{K}_{2} \mathrm{O}$ & 4.52 & 4.26 & 4.23 & 4.52 & 4.67 & 4.28 & 4.55 & 4.22 & 4.5 & 4.42 \\
\hline $\mathrm{P}_{2} \mathrm{O}_{5}$ & 0.01 & 0.05 & 0.01 & 0.02 & 0.01 & 0.01 & 0.01 & 0.01 & 0.01 & 0.02 \\
\hline L.O.I & 0.47 & 0.66 & 0.31 & 0.54 & 0.54 & 0.64 & 0.78 & 0.23 & 0.49 & 0.52 \\
\hline Total & 99.2 & 99.4 & 99.6 & 99.1 & 99.1 & 99.9 & 99.5 & 99.4 & 100 & 99.5 \\
\hline $\mathrm{Cr}$ & 3 & 2 & 10 & 50 & 1 & 2 & 3 & 4 & 1 & 8.4 \\
\hline $\mathrm{Ni}$ & 2 & 2 & 3 & 2 & 2 & 2 & 2 & 3 & 3 & 2.3 \\
\hline $\mathrm{Cu}$ & 2 & 6 & 14 & 6 & 5 & 11 & 5 & 3 & 6 & 6.4 \\
\hline $\mathrm{Pb}$ & 7 & 10 & 24 & 15 & 19 & 17 & 14 & 21 & 42 & 18.8 \\
\hline $\mathrm{Zn}$ & 80 & 107 & 121 & 31 & 78 & 24 & 48 & 188 & 131 & 89.8 \\
\hline $\mathrm{Ga}$ & 37 & 25 & 39 & 28 & 31 & 26 & 30 & 46 & 36 & 33.1 \\
\hline $\mathrm{Ba}$ & 26 & 339 & 12 & 125 & 78 & 41 & 57 & 9 & 47 & 81.6 \\
\hline $\mathrm{Rb}$ & 234 & 104 & 263 & 165 & 140 & 192 & 119 & 423 & 208 & 205.3 \\
\hline $\mathrm{Sr}$ & 7 & 59 & 6 & 30 & 18 & 15 & 14 & 6 & 14 & 18.8 \\
\hline $\mathrm{Y}$ & 88 & 81 & 117 & 75 & 90 & 62 & 89 & 140 & 115 & 95.2 \\
\hline $\mathrm{Zr}$ & 175 & 263 & 125 & 142 & 202 & 108 & 201 & 211 & 173 & 177.8 \\
\hline $\mathrm{Nb}$ & 71 & 48 & 81 & 48 & 61 & 66 & 48 & 113 & 71 & 67.4 \\
\hline $\mathrm{Ta}$ & 5 & 3 & 7 & 5 & 4 & 4 & 3 & 16 & 5 & 5.8 \\
\hline Sn & 13 & 14 & 17 & 9 & 11 & 14 & 7 & 90 & 21 & 21.8 \\
\hline $\mathrm{Hf}$ & 8 & 3 & 7 & 4 & 8 & 4 & 7 & 18 & 9 & 7.6 \\
\hline $\mathrm{U}$ & 4 & 14 & 7 & 6 & 6 & 11 & 4 & 19 & 5 & 8.4 \\
\hline Th & 15 & 17 & 18 & 20 & 13 & 27 & 14 & 29 & 14 & 18.6 \\
\hline $\mathrm{Th} / \mathrm{U}$ & 3.8 & 1.2 & 2.6 & 3.3 & 2.2 & 2.5 & 3.5 & 1.5 & 2.8 & 2.6 \\
\hline
\end{tabular}

Table 2. Rare earth elements (ppm) of granite, El Atawi area.

\begin{tabular}{ccccc}
\hline sample & At 7 & At 11 & At 13 & Average \\
\hline La & 91 & 17 & 47 & 51.7 \\
Ce & 129.2 & 57.9 & 87.5 & 91.5 \\
Pr & 20.6 & 10.5 & 10.9 & 14 \\
$\mathrm{Nd}$ & 75.3 & 25.8 & 27.9 & 43 \\
\hline
\end{tabular}




\section{Continued}

\begin{tabular}{|c|c|c|c|c|}
\hline $\mathrm{Sm}$ & 11.1 & 4.1 & 4.4 & 6.5 \\
\hline $\mathrm{Eu}$ & 0.01 & 0.01 & 0.01 & 0.01 \\
\hline $\mathrm{Gd}$ & 13.5 & 4.8 & 5 & 7.8 \\
\hline $\mathrm{Tb}$ & 1.5 & 2 & 1 & 1.5 \\
\hline Dy & 7.4 & 11 & 9.2 & 9.2 \\
\hline Ho & 2.3 & 3.1 & 3.3 & 2.9 \\
\hline Er & 11 & 8.3 & 9.7 & 9.7 \\
\hline $\mathrm{Yb}$ & 8 & 8 & 23 & 13 \\
\hline$\sum$ REEs & 370.9 & 152.5 & 228.9 & 250.8 \\
\hline LREE & 340.71 & 120.11 & 182.71 & 214.51 \\
\hline HREE & 30.20 & 32.40 & 46.20 & 36.30 \\
\hline$(\mathrm{LREE} / \mathrm{HREE})_{\mathrm{N}}$ & 4.92 & 1.53 & 1.76 & 2.58 \\
\hline$(\mathrm{La} / \mathrm{Yb})_{\mathrm{N}}$ & 7.67 & 1.44 & 1.38 & 2.69 \\
\hline$(\mathrm{La} / \mathrm{Sm})_{\mathrm{N}}$ & 5.16 & 2.61 & 6.72 & 5.01 \\
\hline$(\mathrm{Gd} / \mathrm{Yb})_{\mathrm{N}}$ & 1.36 & 0.48 & 0.18 & 0.49 \\
\hline$\left(\mathrm{Eu} / \mathrm{Eu}^{*}\right)_{\mathrm{N}}$ & 0.003 & 0.007 & 0.007 & 0.004 \\
\hline$t_{1}$ & 0.9 & 1.7 & 1.2 & 1.1 \\
\hline$t_{3}$ & 0.7 & 1.3 & 0.8 & 0.9 \\
\hline $\mathrm{T}$ & 0.8 & 1.5 & 1 & 1 \\
\hline
\end{tabular}

\section{Petrography}

The granites exhibit medium to coarse-grained hypidiomorphic texture and are composed essentially of k-feldspar, quartz, plagioclase, biotite with minor hornblende and muscovite. Zircon, fluorite, sphene, tourmaline and iron oxides are the common accessory minerals while chlorite, epidote, kaolinite and sericite are the alteration mineral constituents.

Potash feldspars occur mostly as large subhedral to anhedral tabular crystals of perthitic orthoclase and microcline with subordinate amounts of microcline up to $3 \mathrm{~mm}$ long. They poikilitically enclose minute crystals and laths of plagioclase, quartz, biotite, sphene, epidot and zircon.

The perthitic texture is formed of flake-like bodies along the cleavage of the k-feldspar host. Sometimes they crosscut the twining planes of microcline (Figure 2(a)). The perthite bodies exhibit a diversity of forms including rod, band, string, braid, flame, patch and vein (Figures 2(b)-(d)).

Quartz occurs as coarse subhedral crystals, $2-3 \mathrm{~mm}$ across or as fine interstitial crystals having sutured outlines. Minute inclusions of quartz occur within feldspars and biotite.

Plagioclase occurs as subhedral prismatic crystals up to $2 \mathrm{~mm}$ long between k-feldspare and quartz. These crystals are usually zoned and saussuritized (Figure 2(e)). Plagioclase occurs also as fine lath-like crystals up to $0.5 \mathrm{~mm}$ long. These crystals are usually fresh, euhedral, unzoned and display well developed polysynthetic twinning. Fine-grained subhedral poikilitic plagioclase inclusions 

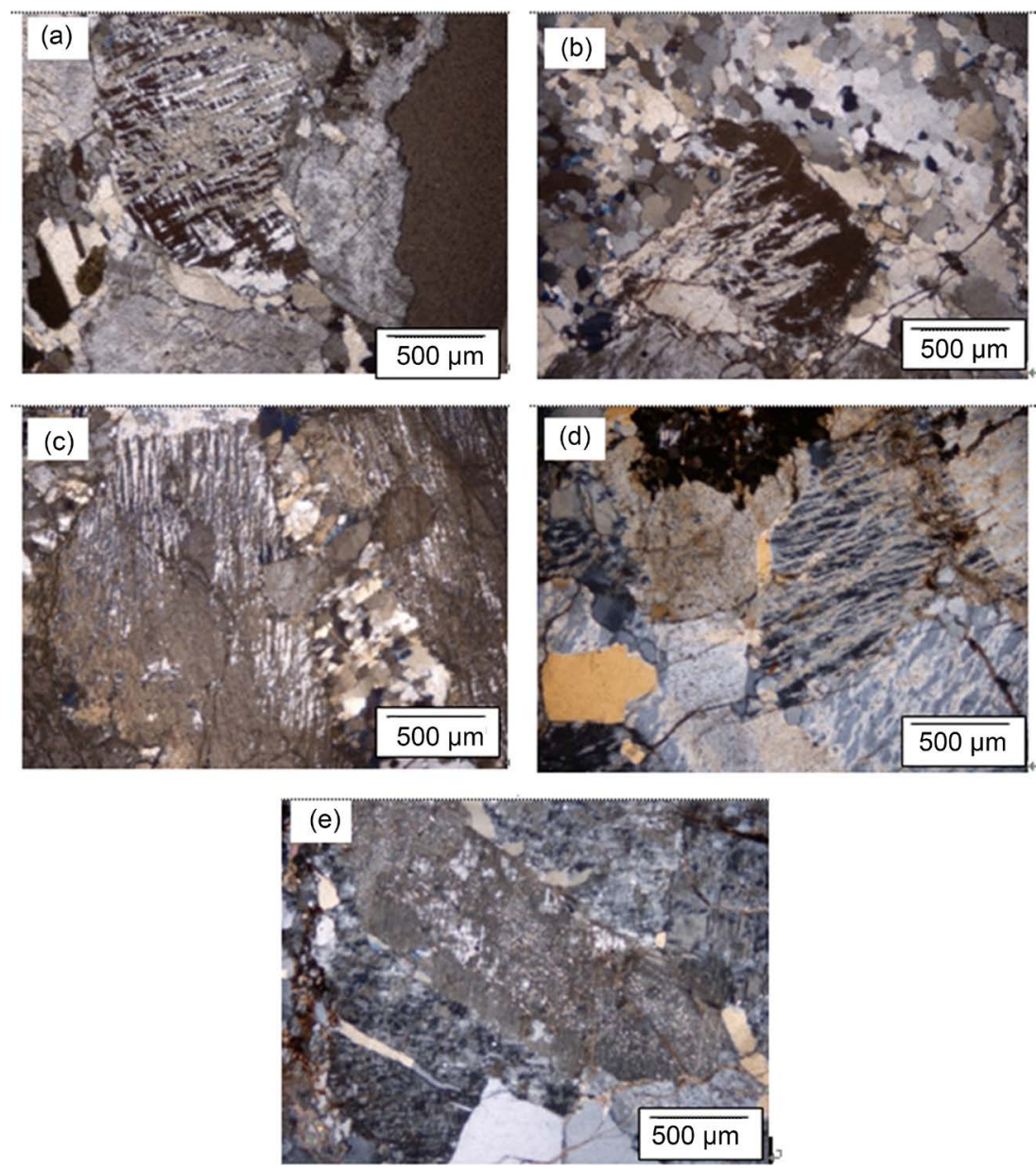

Figure 2. Photomicrographs, Gabal El Atawi granite showing: (a) Perthitic bodies crosscut the twining planes of the microcline host. (b) Rod perthite. (c) String perthite. (d) Braid perthite (upper) and flame perthite (lower). (e) Prismatic zoned and saussuritized plagioclase crystal.

within the k-feldspare crystals are common.

Biotite exists as thick greenish brown to yellowish brown flakes and laths up to $3 \mathrm{~mm}$ long (Figure 3(a)). They sometimes enclose minute crystals of zircon and quartz.

Few interstitial flakes of hornblende and muscovite are recorded (Figure 3(b)). Zircon crystals are euhedral to subhedral and characterized by the presence of pleochroic haloes. Fluorite occurs as grains associated with mica minerals.

In the altered granite samples, the k-feldspar includes small plagioclase crystals along the margins (Figure $3(\mathrm{c})$ ). Some quartz crystals are displaying undulose extinction and cataclastic-like texture. Quartz forms bands consisting of small deformed, elongated and directed grains bowing around other mineral grains (Figure 3(d)). Less commonly, it occurs as graphic intergrowths between $\mathrm{k}$-feldspar and plagioclase releasing quartz (Figure 3(e)). The graphic quartzfeldspar texture suggests that there was simultaneous crystallization of the two phases, with morphology influenced by the presence of aqueous phase [24]. The graphic quartz-k-feldspar intergrowths considered as products of metasomatic 
alterations and intracrystalline penetration of hydrothermal solutions. Secondary quartz veinlets of fine-grained crystals traversing and surrounding other rock forming minerals are common. Some biotite crystals show bending or curved cleavage pointing to deformation effect. Biotite variably altered to chlorite with release of iron oxides as elongated blebs that arranged along cleavage planes. Tourmaline forms euhedral prismatic zoned crystals up to $2 \mathrm{~mm}$ in length (Figure 3(f)). They exhibit brown cores and yellowish brown rims. Tourmaline and fluorite in the granite are the result of B, F-metasomatism.

\section{Geochemistry and Petrogenesis}

\subsection{Geochemical Characteristics and Classification}

The analyzed granites are highly fractionated as indicated from the high $\mathrm{SiO}_{2}$ (range from 74.65 to $77.19 \%$ ). They have also high $\mathrm{Fe}_{2} \mathrm{O}_{3}$ and alkalis, low concentrations of $\mathrm{Al}_{2} \mathrm{O}_{3}, \mathrm{CaO}, \mathrm{TiO}_{2}, \mathrm{MnO}$ and $\mathrm{MgO}$ (Table 1). Decrease of $\mathrm{MgO}$ and $\mathrm{TiO}_{2}$ contents suggests fractionation of mafic minerals along with feldspars [25]. There is a slight excess of $\mathrm{K}_{2} \mathrm{O}$ relative to $\mathrm{Na}_{2} \mathrm{O}$ in granite with $\mathrm{Na}_{2} \mathrm{O} / \mathrm{K}_{2} \mathrm{O}$
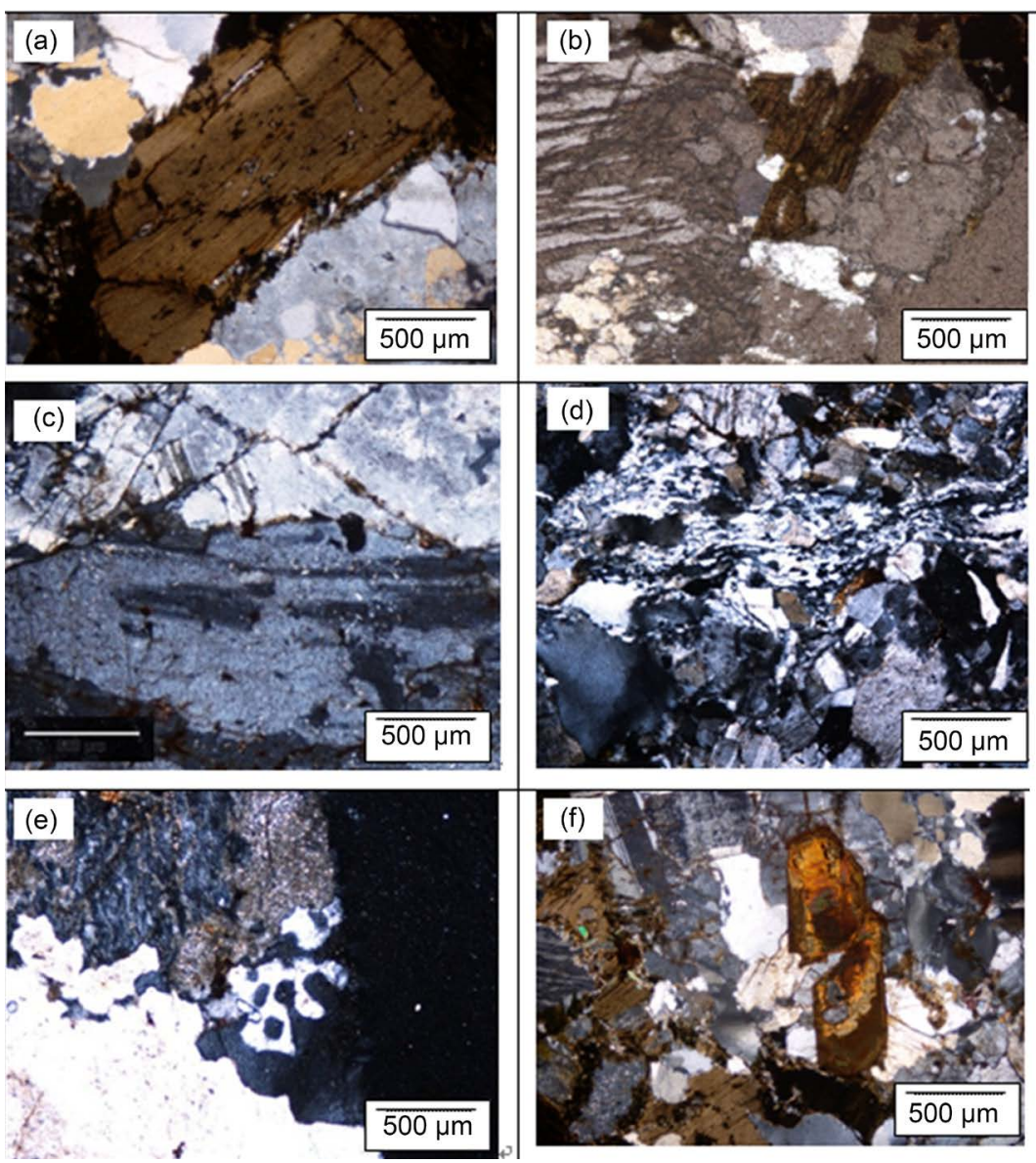

Figure 3. Photomicrograph, Gabal El Atawi granite showing: (a) Biotite flake. (b) Interstitial flakes of hornblende. (c) Metasomatic albite laths replacing perthitic k-feldspar at the margins. (d) Quartz forming bands of small, deformed, elongated and directed grains bowing around other mineral grains. (e) Graphic intergrowth between k-feldspar and plagioclase releasing quartz. (f) Euhedral prismatic zoned tourmaline crystal. 
ratio $<1(0.94)$.

In chondrite-normalized spider diagram (after [26]) (Figure 4), the studied granites are enriched in $\mathrm{Ba}, \mathrm{Rb}, \mathrm{Y}, \mathrm{Zr}, \mathrm{Nb}, \mathrm{Th}, \mathrm{U}$ and depleted in $\mathrm{K}$ while $\mathrm{Sr}$ approaches the unity line. The Th, $\mathrm{U}$ and Ta concentrations exhibit the highest peaks.

Obeid [16] recorded high fluorine concentration in the El Atawi granite (2435 ppm) similar to F-bearing granite elsewhere in the world. Fluorine enrichment in this granite is manifested by the presence of fluorite and tourmaline as accessory minerals. The pervasive occurrence of fluorite in the alkali-feldspar granite reflects its high F concentration [27] [28] [29].

The studied Gabal El Atawi granite samples fall in the alkali granite field of [30] and [31] (Figure 5(a), Figure 5(b)), and in the alkali-feldspar granite field of [32] and [33] (Figures 5(c), Figure 5(d)).

El Atawi alkali feldspar granites are characterized by $\Sigma$ REEs contents ranging from 152.5 to 370.9 with an average $(250.8 \mathrm{ppm})$. They display $\Sigma$ LREEs $(214.5$ ppm) and $\Sigma$ HREEs (36.3 ppm). They show LREE enrichment $(\mathrm{La} / \mathrm{Yb})_{\mathrm{N}}=3.5$, highly fractionated LREEs $(\mathrm{La} / \mathrm{Sm})_{\mathrm{N}}=5$ while HREEs have limited degree of fractionation $(\mathrm{Gd} / \mathrm{Yb})_{\mathrm{N}}=0.49$. They exhibit strong negative Eu anomaly with $\left(\mathrm{Eu} / \mathrm{Eu}^{*}\right)_{\mathrm{N}}$ ranging from 0.003 to 0.007 with an average of 0.006 (Table 2).

$(\mathrm{La} / \mathrm{Yb})_{\mathrm{N}},(\mathrm{La} / \mathrm{Sm})_{\mathrm{N}}$ and $(\mathrm{Gd} / \mathrm{Lu})_{\mathrm{N}}$ ratios are used as a measure of the degree of fractionation of REEs, LREEs and HREEs respectively. The Eu-anomaly is estimated as $\left(\mathrm{Eu} / \mathrm{Eu}^{*}\right)_{\mathrm{N}}$ ratio (Table 2$)$. The chondrite-normalized REEs distribution patterns of El Atawi granite, using the values of Taylor and McLennan [26], show a gull-wing shape with negative slope and strongly negative Eu anomalies (Figure 6).

\subsection{Magma Type}

In the alkali-silica diagram of [34], the rocks show sub-alkaline characters (Figure 7(a)). In the AFM ternary diagram of [34], all the samples fall within the calc-alkaline field (Figure $7(\mathrm{~b})$ ). The analyzed samples plot nearby the alkali

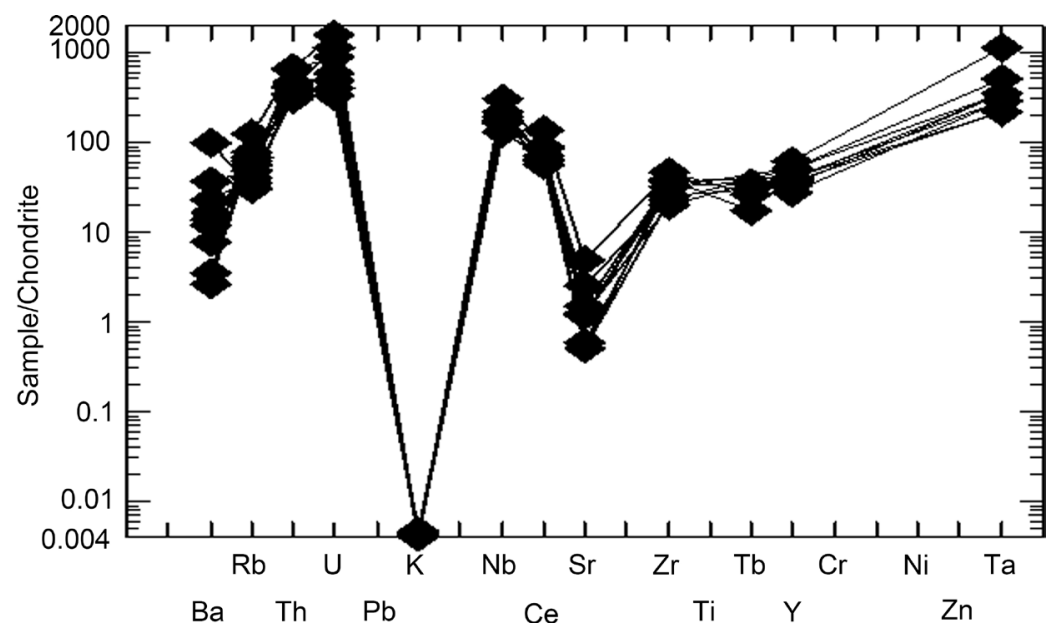

Figure 4. Spider diagram for chondrite-normalized trace elements of Gabal El Atawi younger granites. Normalization values after [26]. 

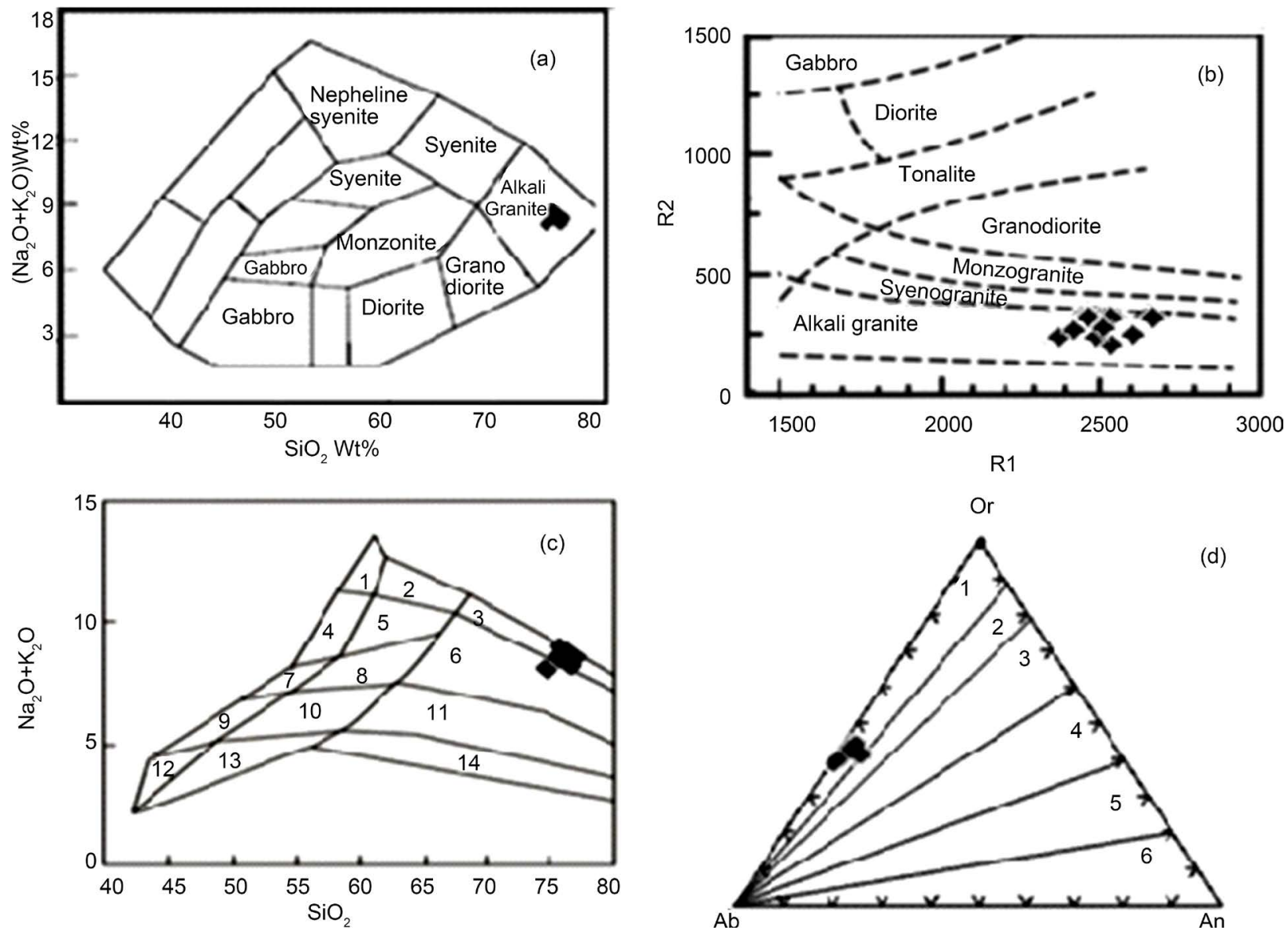

Figure 5. (a): $\mathrm{SiO}_{2}$ vs. $\mathrm{Na}_{2} \mathrm{O}+\mathrm{K}_{2} \mathrm{O}$ variation diagram [30]. (b) $\mathrm{R} 1-\mathrm{R} 2$ binary diagram [31]. $\mathrm{R} 1=4 \mathrm{Si}-11(\mathrm{Na}+\mathrm{K})-2(\mathrm{Fe}+\mathrm{Ti})$ and $\mathrm{R} 2=6 \mathrm{Ca}+2 \mathrm{Mg}+\mathrm{Al}$. (c) $\mathrm{SiO}_{2}$ versus alkalis diagram [32]. $3=$ Alkali feldspar granite, 6 = granite. (d) Normative An-Ab-Or ternary diagram [33]. 1 = Alkali-feldspar granite, 2 = syenogranite.

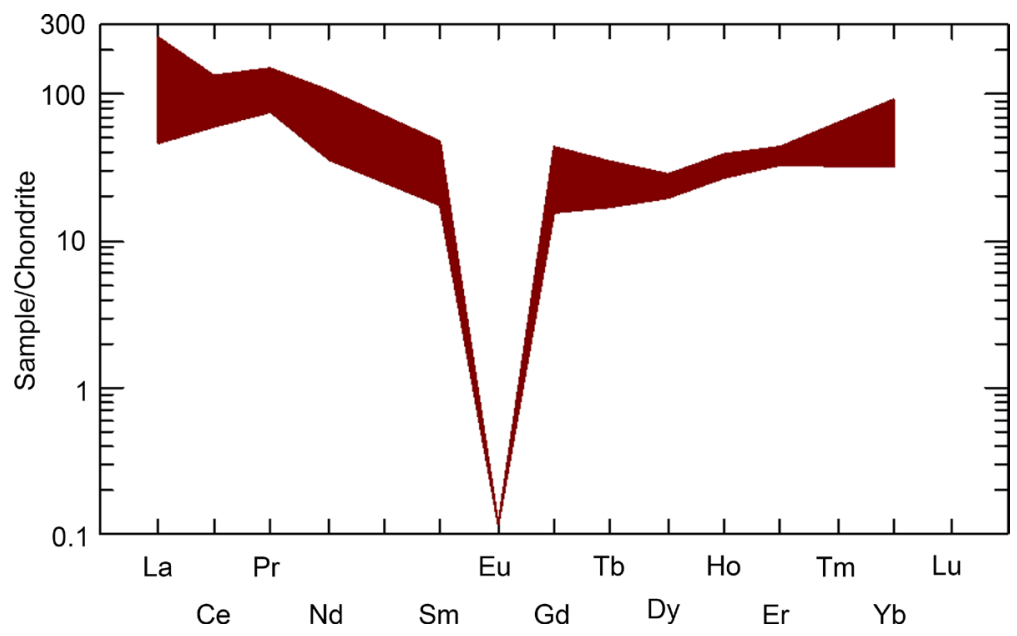

Figure 6. Normalized REE pattern of the younger granite of El Atawi area (normalization values after [26]).

apex but quite dispersed along the A-F side pointing to origination under extensional environment [35]. In the $(\mathrm{Ga}) / \mathrm{Al}_{2} \mathrm{O}_{3} * 0.5293$ versus $\mathrm{Zr}$ diagram of [36], all the samples fall in the A-type field (Figure $7(\mathrm{c})$ ). The granites show high 
$\mathrm{FeOt} /(\mathrm{FeOt}+\mathrm{MgO})$ ratios $(0.91-0.99)$ to plot within ferroan granites field in the $\mathrm{FeOt} /\left(\mathrm{FeOt}+\mathrm{MgO}\right.$ ) against $\mathrm{SiO}_{2}$ scheme of [37] (Figure 7(d)) exhibiting consistency with worldwide A-type granites. The studied granites plot in the $A_{2}$-type granite field of [38] (Figure 7(e)). This means emplacement from apparent crustal source. Gabal El Atawi granites show FeOt/MgO ratios typical of A-type granites (5.6 - 15.1; av. 9.7), which are higher than those found in I-type and S-type granites [36]. In the $\mathrm{FeO}^{\mathrm{t}} /\left(\mathrm{FeO}^{\mathrm{t}}+\mathrm{MgO}\right)$ vs. $\mathrm{Al}_{2} \mathrm{O}_{3}$ diagram, proposed to make distinction between reduced and oxidized A-type granites [39], they plot in the reduced A-type granites field (Figure 7(f)).

\subsection{Tectonic Setting}

The $\mathrm{Rb}$ versus $(\mathrm{Y}+\mathrm{Nb})$ of [40] and the $\mathrm{Hf}-(\mathrm{Rb} / 10)-(\mathrm{Tax} 3)$ diagram of [41] clear that all the samples fall in the within plate granite field (Figure 8(a), Figure 8(b)). They plot in the $A_{1}$-type field of [42] meaning formation mostly in the intraplate magmatism setting (Figure $8(\mathrm{c})$ ).
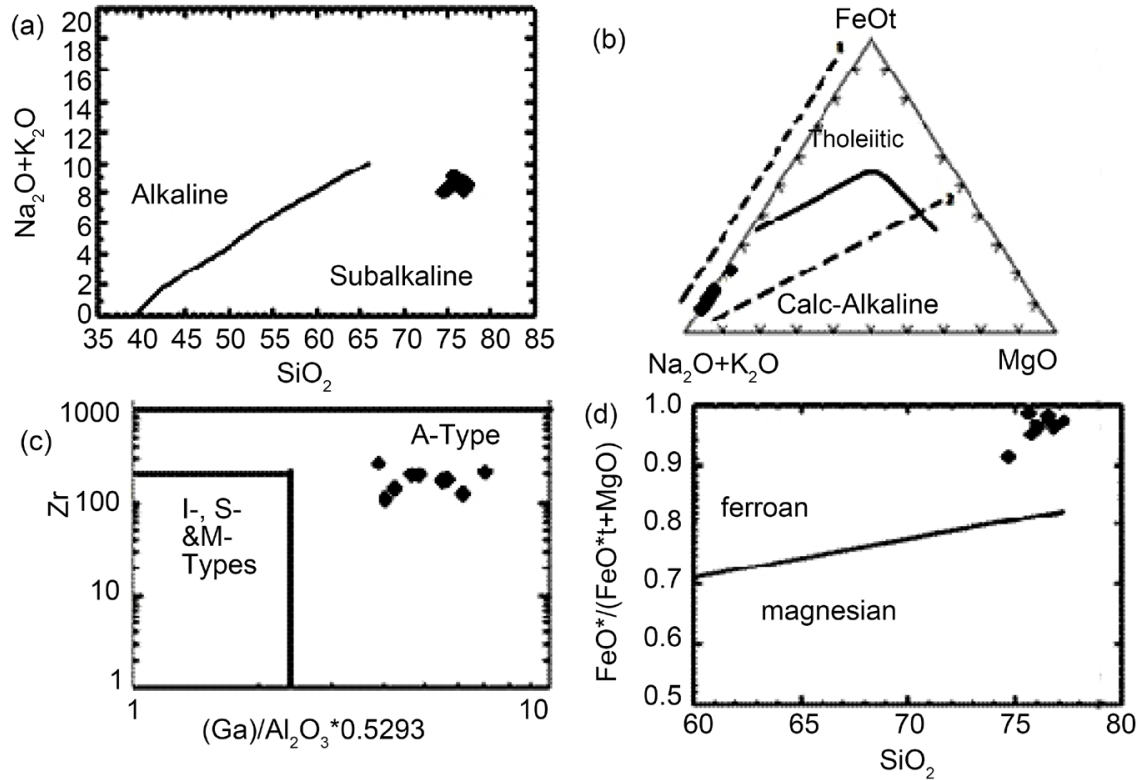

(e)

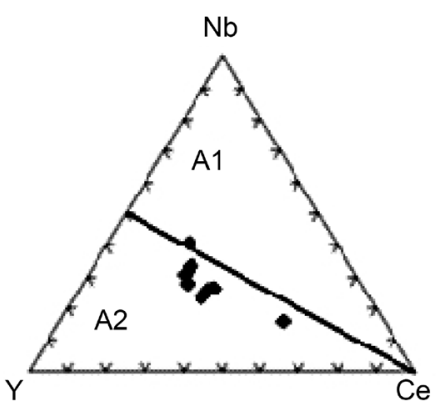

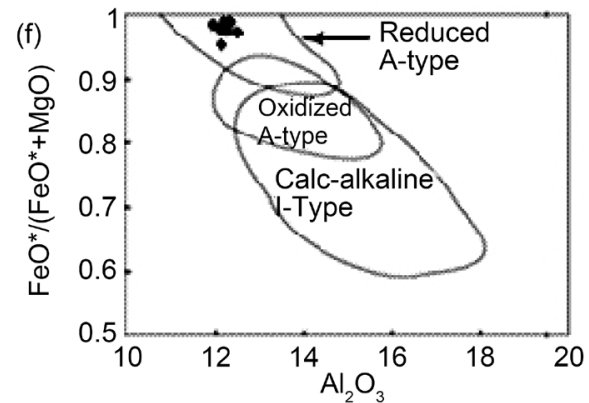

Figure 7. Magma type of El Atawi granite: (a) The total alkalis versus silica diagram [34]. (b) The AFM ternary diagram [34]. The extensional (1) and compressional (2) trends are after [35]. (c) The $\mathrm{Zr}-\left(\mathrm{Ga} / \mathrm{Al}_{2} \mathrm{O}_{3}\right.$ * 0.5293$)$ diagram [36]. (d) $\mathrm{The} \mathrm{FeOt} /(\mathrm{FeOt}+\mathrm{MgO})$ vs. $\mathrm{SiO}_{2}$ [37]. (e) The $\mathrm{Y}-\mathrm{Nb}-\mathrm{Ce}$ ternary diagram [38]. (f) $\mathrm{FeOt} /(\mathrm{FeOt}+\mathrm{MgO})$ vs. $\mathrm{Al}_{2} \mathrm{O}_{3}$ showing the compositional fields of calc-alkaline and A-type granites, and reduced and oxidized A-type granites [39]. 
On the basis of the tectonic discrimination diagrams $\mathrm{Rb}$ versus $(\mathrm{Y}+\mathrm{Nb})$ of [43], $\mathrm{SiO}_{2}$ versus $\mathrm{Al}_{2} \mathrm{O}_{3}$ of [44] and multicationic R1versus $\mathrm{R} 2$ of [45], the studied granite lies in the POG (post-orogenic granite) field (Figure 8(a), Figure 8(d), Figure 8(e)).
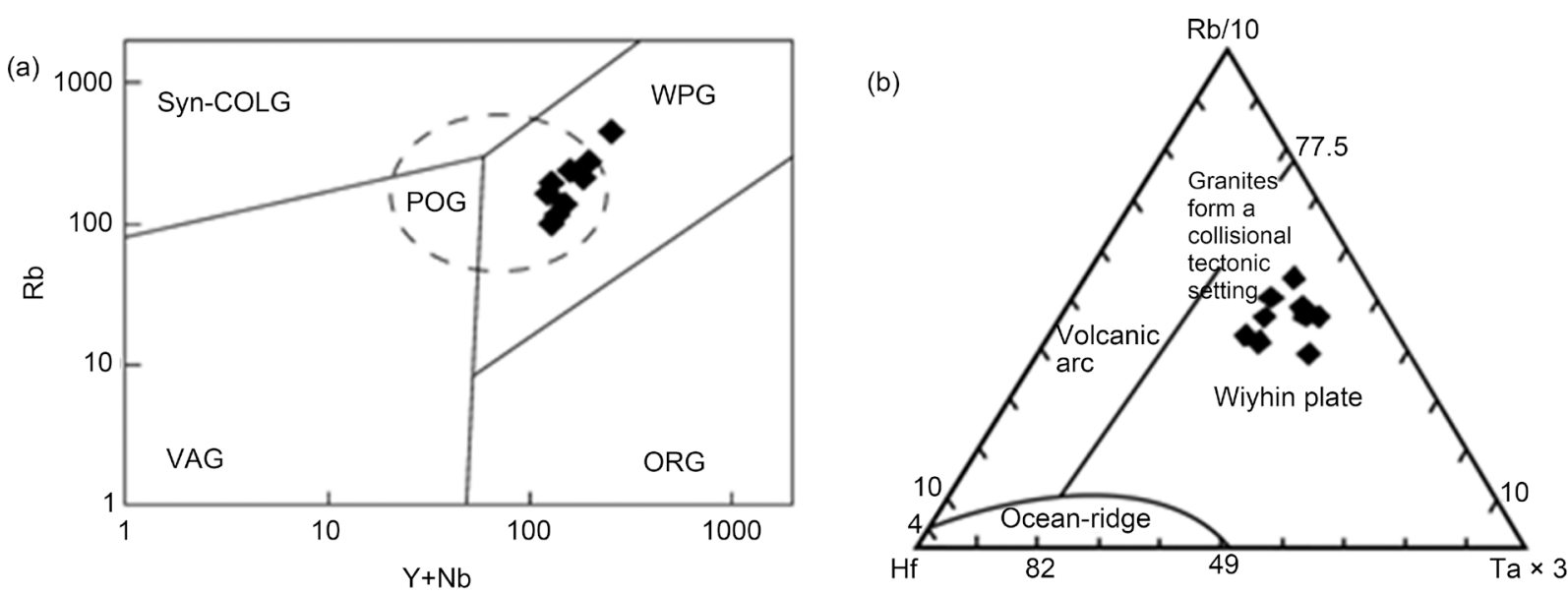

(c)

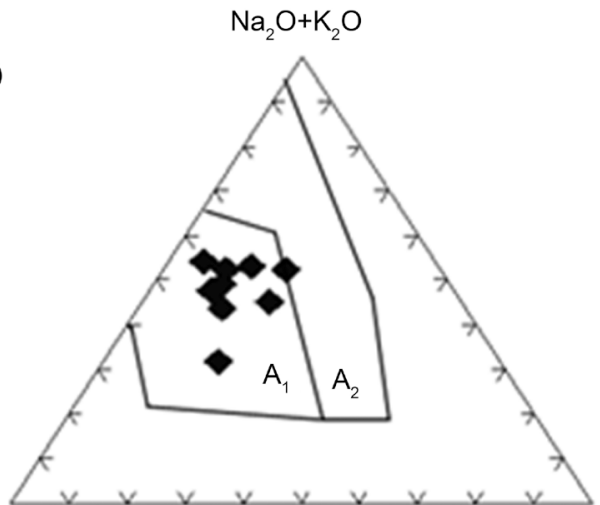

(d)

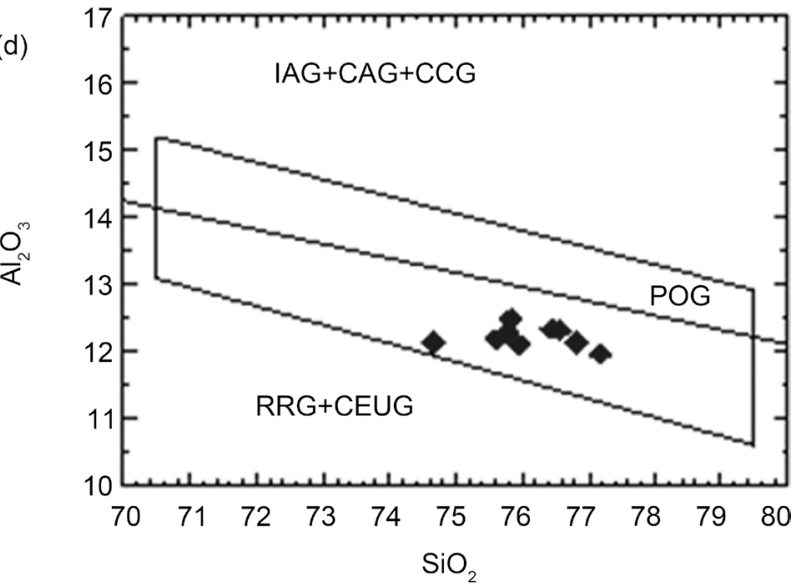

(e)

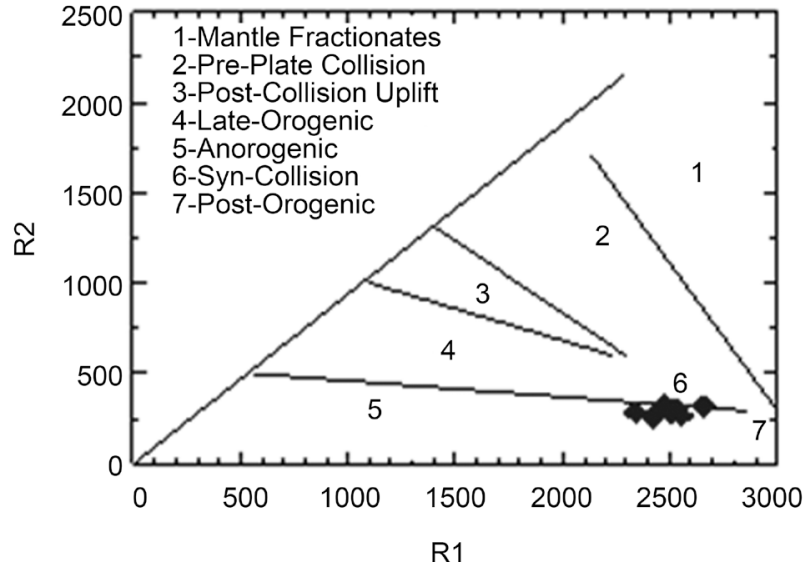

Figure 8. Tectonic setting of El Atawi granite. (a) $\mathrm{Rb}-(\mathrm{Y}+\mathrm{Nb})$ diagram [40]. VAG = volcanic arc granite, ORG $=$ oceanic ridge granite, Syn-COLG = syn-collision granite and WPG = within-plate granite, POG post collision granite field. (b) Hf-Rb/10-Tax3 diagram [41]. (c) $\mathrm{Na}_{2} \mathrm{O}+\mathrm{K}_{2} \mathrm{O}-\mathrm{Fe}_{2} \mathrm{O}_{3}{ }^{*} \times 5-(\mathrm{CaO}+\mathrm{MgO}) \times 5$ diagram [42]. (d) $\mathrm{SiO} 2$ vs. $\mathrm{A}_{2} \mathrm{O}_{3}$ diagram [44]. Orogenic: Island arc granite (IAG), Continental arc granite (CAG), Continental collision granites (CCG), Post orogenic granites (POG). Anorogenic: Rift-related granites (RRG), Continental epiorogenic granite (CEUG). (e) Multicationic R1 - R2 diagram [45]. 
The REEs distribution patterns of El Atawi granite (Figure 6) show the characteristic features of A-type F-bearing granite [46]. In igneous environments (relative reducing conditions) europium is almost entirely present as divalent state $\left(\mathrm{Eu}^{2+}\right)$. So, unlike the rest of the REEs $\left(\operatorname{Ln}^{3+}\right)$, which are mainly associated with accessory minerals [47], $\left(\mathrm{Eu}^{2+}\right)$ partitions 20 to 100 times more efficiently in plagioclase [48] replacing $\mathrm{Ca}^{2+}, \mathrm{Sr}^{2+}$ and $\mathrm{Na}^{+}$[49]. This anomalous behavior is of particular interest and makes "Eu" acts as a sensitive indicator for destruction of plagioclase structure.

Schnetzler and Philpotts [50] stated that the uptake of $\mathrm{Eu}^{+2}$ by plagioclase depends upon the anorthite content (since $\mathrm{Eu}^{+2}$ substitutes for $\mathrm{Ca}$ in the plagioclase structure). This would reduce the Eu content of the more sodic plagioclase and consequently the more fractionated rocks. The negative Eu anomaly indicates its depletion in the medium. The late magmatic melt is diagnostically defict in Eu [51]. Eu anomalies $\left(\mathrm{Eu} / \mathrm{Eu}^{\star}\right)$ are commonly explained by feldspar fractionation [52]. The strong Eu depletion in the late-stage of granitic crystallization may indicate a preferential Eu fractionation into a co-existing aqueous fluid phase rather than into feldspar [53]. This is most probably the case in the studied granites.

The tetrad effect in lanthanide patterns of whole-rock samples was quantified by Eqns. 1, 2 and 3 proposed by [54]. The calculated sizes $t_{1}, t_{3}$ and $T$ of the tetrad effect are listed in Table 2 . The studied granite shows a pattern with convex first tetrad effect $\left(t_{1}=1.1\right)$ while the calculated sizes $t_{3}$ and $T$ of the tetrad effect are below the level of significance (1.1). The low calculated tetrad effects indicated that the distribution of REE is due to magmatic fractionation. The late stage fluid-melt interaction possibly affected the size of the tetrad effect of individual tetrads and may have influenced the anomalous enrichment of different elements in the younger granites [55]. Curved segments in normalized whole rock REE patterns can be introduced during hydrothermal fluid-rock interaction [56]. The primary cause of the tetrad effect, i.e., magma-fluid interaction, has not only depleted $\mathrm{Eu}$ in the rock, but also resulted in unusual negative Eu anomalies in all constituent minerals including K-feldspars. This may have caused the first te$\operatorname{trad}\left(t_{1}\right)$ in the El Atawi younger granites.

The parent magma for the studied granites have undergone extensive magmatic differentiation, during which intense interaction of the residual melt with aqueous hydrothermal fluids most probably rich in $\mathrm{F}$ (as indicated from the presence of fluorite and tourmaline and the high fluorine content in the rocks) resulted in the first tetrad effect of REEs distribution.

In water-saturated $\mathrm{Q}-\mathrm{Ab}-\mathrm{Or}-\mathrm{H}_{2} 2 \mathrm{O}$ system of [57], the investigated granites plot very close to the line joining the minimum melt compositions for different $\mathrm{P}\left(\mathrm{H}_{2} \mathrm{O}\right)$, ranging 0.5 - 3 kbars indicating a low water pressure during the evolution of these granites. The studied granites have been generated at range of crystallization temperatures from $\sim 740^{\circ} \mathrm{C}$ to $800^{\circ} \mathrm{C}$ (Figure 9(a)).

The chondritic $\mathrm{K} / \mathrm{Rb}$ ratio is 242 [58], the average of magmatic rocks is given as 230 , with most of the crustal rocks ranging from 150 to 350 [59]. With increasing 
degree of differentiation, $\mathrm{Rb}$ fractionates preferentially into the residual melt and the $\mathrm{K} / \mathrm{Rb}$ ratios decrease in highly evolved magmatic systems below 50. Ratio values less than 100 are regarded to indicate the interaction with an aqueous fluid phase [60] or mineral growth in the presence of aqueous fluids [61]. The $\mathrm{K} / \mathrm{Rb}$ ratio is commonly used to characterize the evolution of granitic magma. In the studied granites, the $\mathrm{K} / \mathrm{Rb}$ ratios are ranging from $<340$ to $>82$. On the $\mathrm{K}-\mathrm{Rb}$ binary diagram (Figure $9(\mathrm{~b})$ ), the studied granite samples plot around the crustal line $(\mathrm{K} / \mathrm{Rb}=250)$ suggested by [59] and away from the mantle line $(\mathrm{K} / \mathrm{Rb}=$ $1,000)$ given by [62]. This reflects their high $K$ content and suggests their derivation from lower crust materials rather than upper mantle source.

Moreover, Mason [63] constructed the K-Ba binary diagram (Figure 9(c)) and suggested the average crustal ratio $(\mathrm{K} / \mathrm{Ba}=65)$. The studied granite samples plotted on this diagram supports their derivation from a crustal material. All the plots are located above the average crustal line, showing relatively $\mathrm{K}$ enrichment and $\mathrm{K} / \mathrm{Ba}$ ratio $>65$.

On the $\mathrm{Ba}-\mathrm{Rb}$ binary diagram of [63], the studied granite samples are plotted below the crustal line $(\mathrm{Ba} / \mathrm{Rb}=4.4)$ (Figure $9(\mathrm{~d}))$. The plots are located around and below the line $\left(\mathrm{Ba} / \mathrm{Rb}=4.4 \times 10^{-1}\right)$. This indicates their derivation from crust at moderate levels (intermediate crust).

$\mathrm{The} \mathrm{Rb} / \mathrm{Sr}$ ratio is used as indicator of magmatic differentiation, where it increases with higher degree of differentiation. The Rb-Sr binary diagram (Figure $9(e))$ indicates that these granites have been derived from highly differentiated and more evolved granitic liquids. The dashed lines on the diagram refer to the crustal thickness [64]. The granites have been emplaced at relatively shallow to moderate depths between 20 and $30 \mathrm{~km}$.

On the $\mathrm{Al}_{2} \mathrm{O}_{3} / \mathrm{TiO}_{2}$ vs. $\mathrm{TiO}_{2}$ diagram (Figure 9(f)) suggested by [65], the studied granitic rocks display a curved trend, typical of magmatic differentiation.

The chondritic ratio of $\mathrm{Y} / \mathrm{HO}$ is 28 [58]. The $\mathrm{Y} / \mathrm{Ho}$ ratio was proposed as a factor to identify non-charge and non-ionic size controlled magmatic trace element behavior such as found in aqueous systems [66]. The fractionation behavior of highly charged ions, which form strong chemical complexes, is additionally influenced by their electron configuration and the character of chemical bonding between a central ion and a ligand. In the studied granites, the average Y/Ho ratio is 32.5. Bau and Dulski [67] suggested the complexation with fluorine as major cause for values $>28$.

The $\mathrm{Zr} / \mathrm{Hf}$ values in granites average at 39 [68]. The chondritic ratio is 38 [58]. $\mathrm{Zr} / \mathrm{Hf}$ ratio decreases with increasing evolution of the silicate melt. In the studied granites, the $\mathrm{Zr} / \mathrm{Hf}$ value is 31 . It is decreased to 11 during the crystallization of the El Atawi granites.

It is clear that the granites under consideration are highly fractionated. However, the investigated relationships on $\mathrm{K}-\mathrm{Rb}, \mathrm{K}-\mathrm{Ba}, \mathrm{Ba}-\mathrm{Rb}$, and $\mathrm{Rb}-\mathrm{Sr}$ diagrams suggest that the granites were derived from crustal materials and the crystal fractionation was the predominant process during magmatic differentiation. 


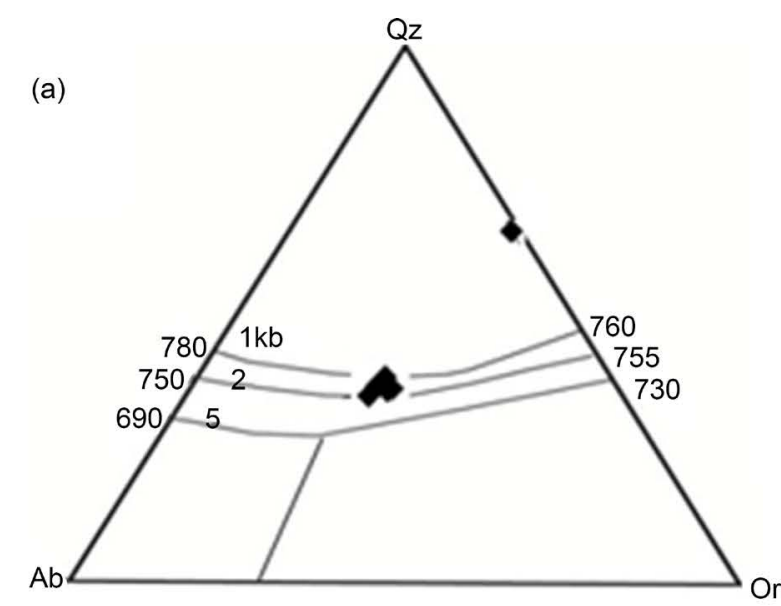

(b)

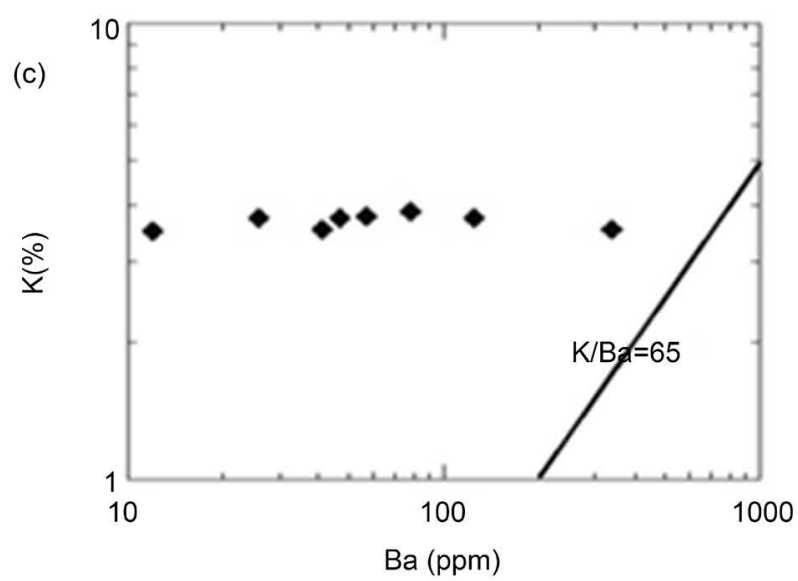

$\mathrm{K}(\%)$
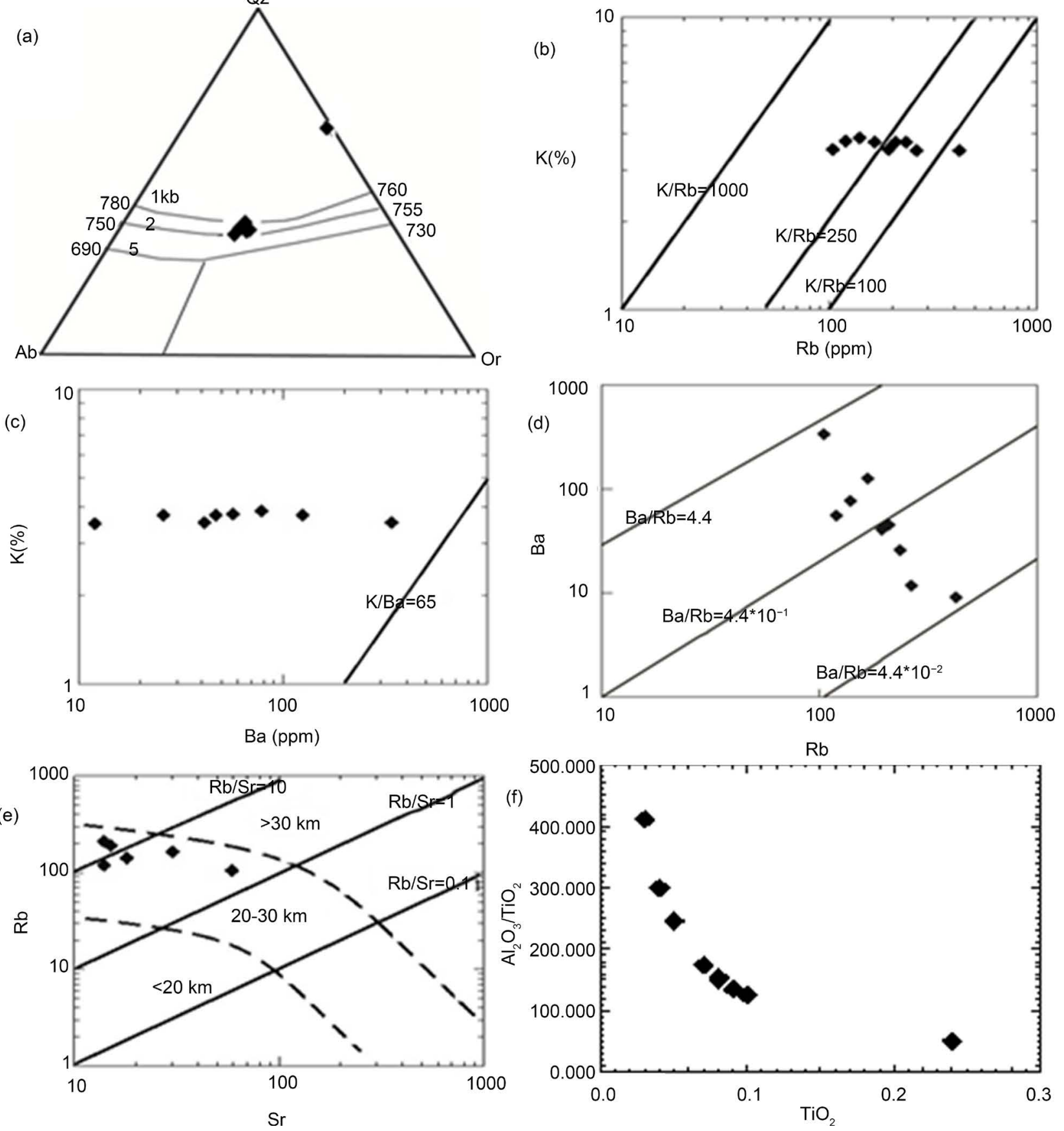

Figure 9. Petrogenesis of Gabal El Atawi granites: (a) Normative Qz-Ab-Or diagram [57] showing cotectic lines and compositions of $\mathrm{H}_{2} \mathrm{O}$-saturated minimum and eutectic melts at given pressures. (b) The $\mathrm{K}$ vs. Rb diagram [62] shows the average crustal $\mathrm{K} / \mathrm{Rb}$ ratio of Taylor [59]. (c) The K-Ba diagram showing the average crustal K/Ba ratio [63]. (d) The Ba-Rb diagram [63]. (e) The Rb-Sr binary diagram. The dashed lines refer to the crustal thickness (after Condie [64]). (f) $\mathrm{Al}_{2} \mathrm{O}_{3} / \mathrm{TiO}_{2}$ vs. $\mathrm{TiO}_{2}$ diagram [65].

\section{Radioactivity}

$\mathrm{U}$ and Th contents in the studied granite are 8.4, $18.6 \mathrm{ppm}$ respectively (Table 1). The ranges and averages $U$ and Th contents of granitic rocks are of [69], (3 ppm $\mathrm{U}$ and 8 - $17 \mathrm{ppm}$ Th), [70], (5 ppm U and 18 - $20 \mathrm{ppm}$ Th), [71] (1 - $6 \mathrm{ppm} \mathrm{U}$ and $1-23 \mathrm{ppm} \mathrm{Th}$ ) and [72], (5 ppm U and $18 \mathrm{ppm} \mathrm{Th}$ ). 
The positive correlation between $U$ and Th (Figure 10(a)) indicates that their distribution was essentially controlled by the magmatic processes. Normally, Th is three times as abundant as uranium in natural rocks [72]. When this ratio is disturbed, it indicates the depletion or enrichment of $U$. This is very evident in the analyzed samples (Figure 10(b)) where the decreasing $\mathrm{Th} / \mathrm{U}$ ratios are accompanied by enrichment in uranium content relative to Th in the granites and that the secondary process played a role in uranium enrichment (uranium had been added to these granites in post magmatic stage). In Figure 10(a), the granite samples fall below the world line of $\mathrm{Th} / \mathrm{U}(=4)$ in granitic rocks of [73] indicating addition of uranium post magmatically during secondary processes. The decreasing trend between Th and Th/U (Figure 10(c)) may indicate small enrichment in $U$ content. The equation $U-(T h / 3.5)$ reflects the uranium mobilization. If the result of this equation equals zero, it indicates that no uranium mobilization took place (i.e. fresh samples). When it is greater than zero, it means that uranium was enriched (added to rock) while the negative values mean uranium leaching out. On the mobility diagram (Figure 10(d)); the plotted samples show $\mathrm{U}-(\mathrm{Th} / 3.5)$ values above zero reaching up to 10.7 indicating uranium enrichment.

The relationships $\mathrm{U}-\mathrm{Th}, \mathrm{U}-\mathrm{Th} / \mathrm{U}$, Th-Th/U and $\mathrm{U}-(\mathrm{Th} / 3.5)$ reflect direct relations (Figures 10(a)-(d)) that means the Th/ $\mathrm{U}$ ratio tends to decrease with uranium mobilization and post magmatic redistribution in the studied granits and this could be a favorable economic criterion in the granites of El Atawi area [74] [75] [76].
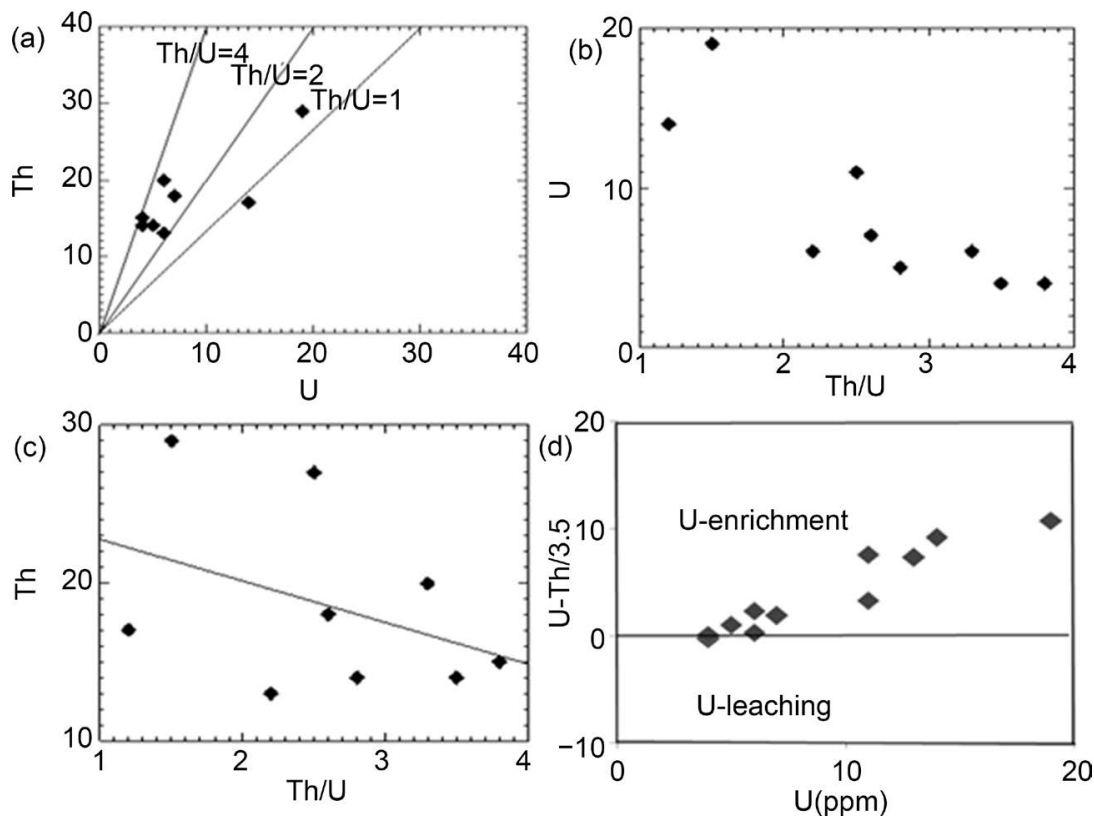

Figure 10. (a) Plotting of El Atawi granites on the $U$ versus Th variation diagram. (b) The $\mathrm{U}$ versus $\mathrm{Th} / \mathrm{U}$ ratio variation diagram. (c) The Th content versus $\mathrm{Th} / \mathrm{U}$ ratio variation diagram. (d) The $\mathrm{U}$ content versus uranium mobilization equation $\mathrm{U}-(\mathrm{Th} / 3.5)$ diagram. 
The poor correlation between $\mathrm{U}$ and silica (Figure 11(a)) indicate the secondary origin of uranium. The positive correlation between Th and silica (Figure 11(b)) indicates that Th distribution is controlled by magmatic processes. Generally, during magmatic differentiation, $\mathrm{U}$ and $\mathrm{Th}$ increase from basaltic to low Ca-granitic rock, but the $\mathrm{Th} / \mathrm{U}$ ratio remains constant. The relation between $\mathrm{Th} / \mathrm{U}$ ratios and $\mathrm{SiO}_{2}$ (Figure 11(c)) shows scatter of data points indicating redistribution of uranium by the post magmatic processes. The positive correlation of $\mathrm{U}$ and $\mathrm{Fe}_{2} \mathrm{O}_{3}$ (Figure 11(d)) suggests that $\mathrm{U}$ is adsorbed on the surface of secondary iron oxides indicating that $\mathrm{U}$ is related to post magmatic processes.

It is well known that if magmatic processes controlled uranium concentration in granitic melt, the elements $\mathrm{U}, \mathrm{Zr}, \mathrm{Y}, \mathrm{Rb}$ and $\mathrm{Nb}$ would be expected to increase. The positive relations $\mathrm{U}-\mathrm{Zr}, \mathrm{U}-\mathrm{Rb}, \mathrm{U}-\mathrm{Nb}$ and $\mathrm{U}-\mathrm{Y}$ (Figure 12) indicate that $\mathrm{U}$ content tends to increase with increasing contents of such elements during the magmatic processes. The faint positive relations suggest that $U$ was added to these rocks during secondary process (post magmatic stage) and support that $U$ does not depend mainly on the zircon as a host mineral.

Thus, uranium enrichment in the studied granites is not only related to magmatic processes but also due to secondary processes.

\section{Fluid Inclusions Studies}

The quartz of the altered granite samples is enriched in two types of fluid inclusions, namely: Type (I) simple fluid rich two-phase (fluid-vapor) inclusions, 10 $40 \mu \mathrm{m}$ across, containing approximately 10 to 40 volume percent of gas. They display oval or elongated shape and distributed in growth zones of the quartz
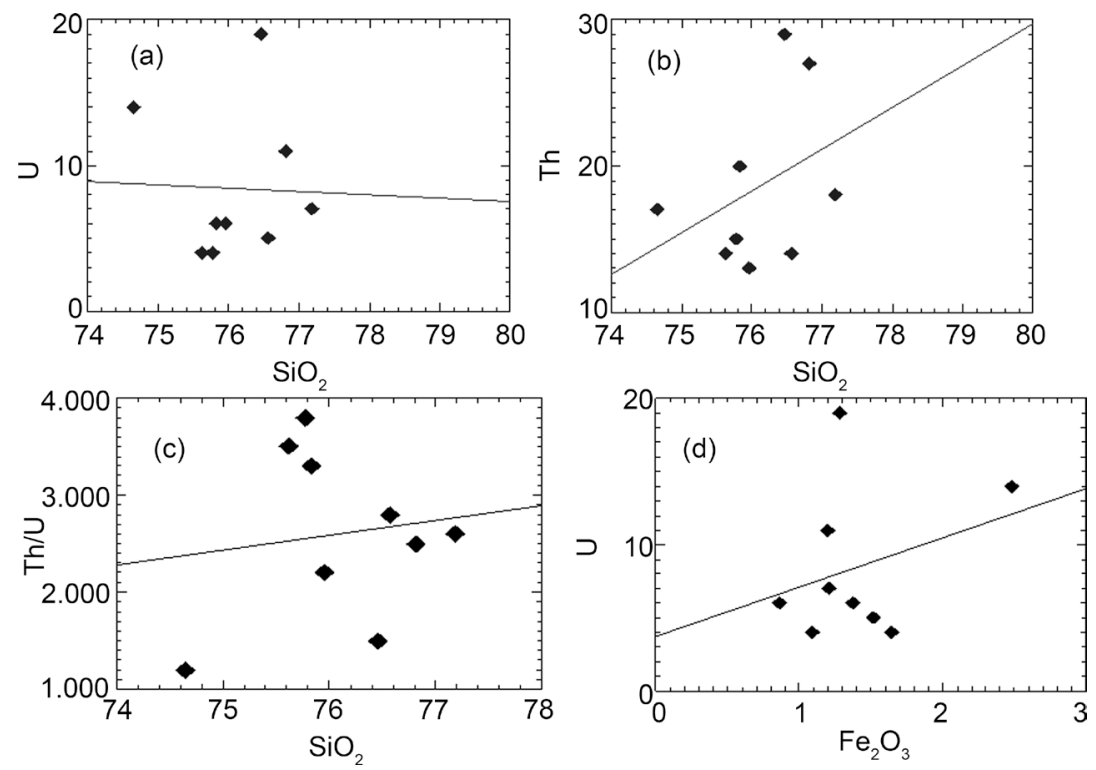

Figure 11. Plotting of El Atawi granites on the (a) $\mathrm{U}$ versus $\mathrm{SiO}_{2}$ variation diagram. (b) Th versus $\mathrm{SiO}_{2}$ variation diagram. (c) Th/U versus $\mathrm{SiO}_{2}$ variation diagram (d) U versus $\mathrm{Fe}_{2} \mathrm{O}_{3}$ variation diagram. 

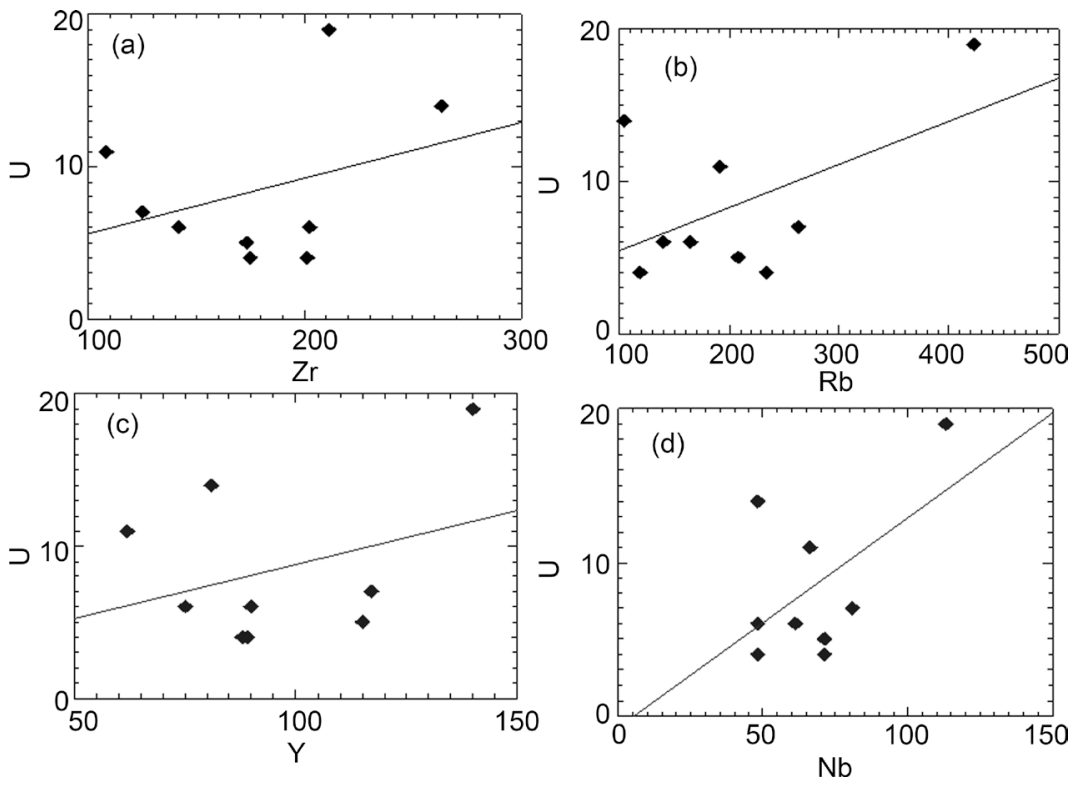

Figure 12. Plotting of El Atawi granites on (a) U versus Zr variation diagram. (b) U versus $\mathrm{Rb}$ variation diagram. (c) $\mathrm{U}$ versus $\mathrm{Nb}$ variation diagram. (d) $\mathrm{U}$ versus $\mathrm{Y}$ variation diagram.

crystals along with crystal inclusions (Figure 13(a)) or irregularly arranged. The shape and spatial distribution of which indicate their primary origin (using the criteria of [77]. Type (II) is secondary two-phase aqueous (fluid-vapor) inclusion. They are concentrated along or near healed fractures and display oval or elongated shape (Figure 13(b)). Their linear dimension does not exceed $15 \mu \mathrm{m}$. These inclusions are the most abundant type in quartz.

Microthermometric determinations were made on type I inclusions. The primary type (I) inclusions homogenize to liquid phase and characterized by a wide range of homogenization temperatures from $394^{\circ} \mathrm{C}$ to $90^{\circ} \mathrm{C}$ that represent minimum trapping temperature (Figure $13(\mathrm{c})$ ). The inclusions contain mineralized fluids (6.2 to 17 ) equiv. wt $\% \mathrm{NaCl}$, with maximum peak at 15 equiv. wt. \% $\mathrm{NaCl}$ (Figure 13(d)). The wide ranges of the homogenization temperature, as well as the presence of more than one peak may reflect the presence of more than one generation of fluids. The fluid evolution in the quartz is shown in Figure 13(e). The inclusions contain two types of solutions according to the degree of homogenization temperature. The first is low temperature fluid $\left(90^{\circ} \mathrm{C}\right.$ to $130^{\circ} \mathrm{C}$ ) which is the dominant with a wide range of salinity (6.2 to 17 equiv. wt\% $\mathrm{NaCl}$ ) and a density of 1.008 to $1.058 \mathrm{~g} / \mathrm{cm}^{3}$. The minimum pressures of trapping are between 100 and 200 bars. The measured eutectic temperatures $\left(\mathrm{T}_{\mathrm{e}}\right)$ in these inclusions range from $-40^{\circ}$ to $-47^{\circ}$. These values of $\mathrm{T}_{\mathrm{e}}$ are typical for the $\mathrm{NaCl}-\mathrm{CaCl}$ solutions. The second solution is characterized by a narrow range of temperature and salinity. It is of moderately high temperature $\left(290^{\circ} \mathrm{C}\right.$ to $\left.294^{\circ} \mathrm{C}\right)$ with salinity ranges from 15 to 17 equiv. wt $\% \mathrm{NaCl}$ and a density of 0.895 to $0.908 \mathrm{~g} / \mathrm{cm}^{3}$. The minimum pressures of trapping are between 80 and 150 bars. The measured eutectic temperatures $\left(\mathrm{T}_{\mathrm{e}}\right)$ in these inclusions are around $-35^{\circ}$. These values of $\mathrm{T}_{\mathrm{e}}$ characterize chloride solutions with $\mathrm{Fe}, \mathrm{Mg}$ and $\mathrm{Na}$ cations. 

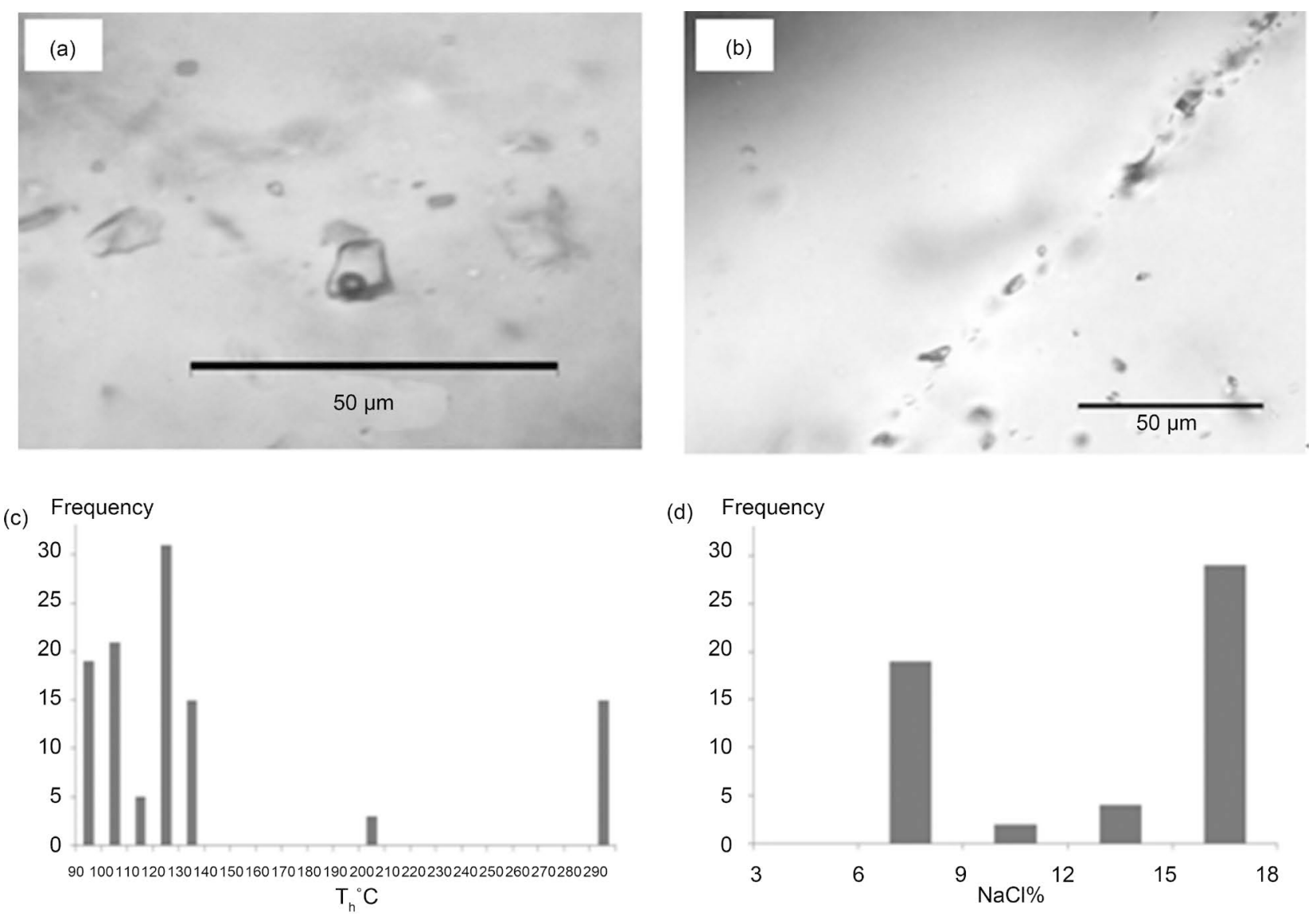

(e)

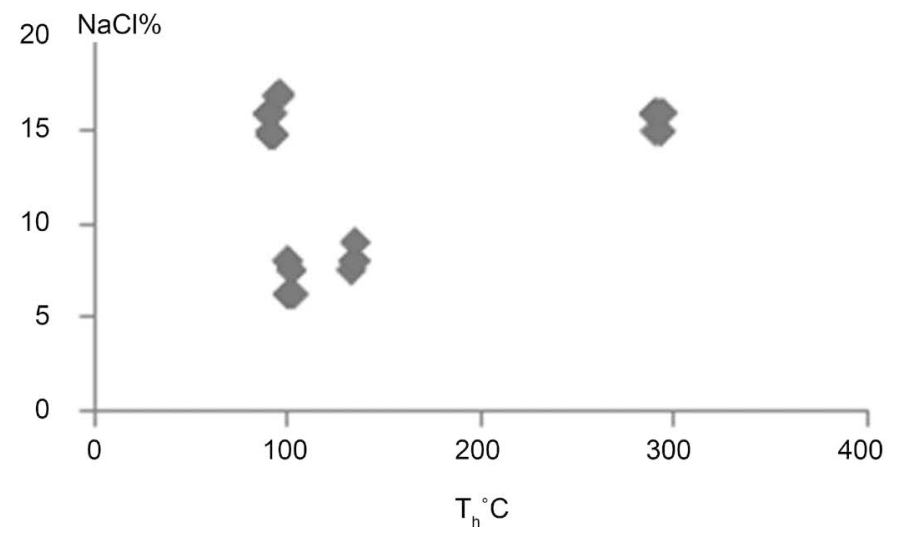

Figure 13. Photomicrographs showing fluid inclusions from the quartz crystals: (a) Type (I) primary two-phase (fluid-vapor) inclosion in growth zones accentuated by numerous crystal inclusions. (b) Type (II) secondary two phase aqueous (fluid-vapor) inclusion with different degree of filling concentrated a'long healed fractures. (c) Homogenization temperatures of primary fluid inclusions in quartz. (d) Salinity of primary fluid inclusions in quartz. (e) Homogenization temperature vs. concentration of solution of fluid inclusions in quartz.

\section{Discussion}

Fertile granites display the following specific features:

1) Petrographically, uraniferous granites are a two-mica and two-feldspars leucogranite in which plagioclase is mainly albite [75] [78] [79]. The fertile granites contain little amounts of fluorite [80]. El Atawi granite is two-feldspar granite and contains disseminated fluorite. 
2) Geochemically, uraniferous granite displays high contents of $\mathrm{SiO}_{2}(>73 \%), \mathrm{Rb}$ $(>200 \mathrm{ppm}) \mathrm{Zr}(>140 \mathrm{ppm})$, REE with negative $\mathrm{Eu}^{*}$ anomaly as well as high $\mathrm{Zr} / \mathrm{Sr}(>1.65-5.14), \mathrm{Rb} / \mathrm{Sr}(>2.5)$ and $\mathrm{K} / \mathrm{Rb}(>125)$ ratios. It is low in $\mathrm{CaO}$ $(<1 \%)$, L.O.I. $(<1 \%), \mathrm{Ba}(<298 \mathrm{ppm}), \mathrm{Sr}(<99 \mathrm{ppm})$ and $\mathrm{Na}_{2} \mathrm{O} / \mathrm{K}_{2} \mathrm{O}(1.11)$. Uraniferous granite is always post orogenic and derived mainly from felsic continental crust [75] [78] [81]. El Atawi granite displays high $\mathrm{SiO}_{2}$ (76.1\%), $\mathrm{Rb}$ (205.33 ppm), $\mathrm{Zr}$ (177.78 ppm), REE with negative $\mathrm{Eu}^{*}$ anomaly as well as high $\mathrm{Zr} / \mathrm{Sr}$ (15.04), $\mathrm{Rb} / \mathrm{Sr}(22.4)$ and $\mathrm{K} / \mathrm{Rb}$ (211.51) ratios. It is low in $\mathrm{CaO}$ (0.49\%), L.O.I. (0.52\%), $\mathrm{Ba}(81.6 \mathrm{ppm}), \mathrm{Sr}(18.8 \mathrm{ppm})$ and $\mathrm{Na}_{2} \mathrm{O} / \mathrm{K}_{2} \mathrm{O}(0.94)$. They are calc-alkaline, post-orogenic and have been derived from crustal material.

3) Darnely [72] defined uraniferous granites as any granitic masses containing $\mathrm{U}$ at least twice the Clarke value (4.0 ppm). Uraniferous granites must have $\mathrm{U}$ content (>8 - 20), Th content (>11 ppm) and a Th/U (2.2 - 3.5) [76] [78] [81]. El Atawi granites contain average $\mathrm{U}$ and Th contents $(8.4$ and $18.6 \mathrm{ppm}$ respectively) and $\mathrm{Th} / \mathrm{U}$ ratio (2.6) which all the way through being interpreted as a definition of uraniferous granites.

The overall presented data elucidated that El Atawi granites meet and fulfill the requirements of being fertile granites and they can be considered as promising uraniferous granites.

The studied granites were obviously subjected to various alteration processes (hematitization, kaolinitization and fluortization). The alteration zones show the highest $\mathrm{U}$ and $\mathrm{Th}$ contents as a result of alteration processes. Fluid inclusion studies of the investigated altered granite were conducted to elucidate the characters of hydrothermal solutions acting on the host granitic pluton. It is possible to define two different acting solutions. The first is $\mathrm{NaCl}-\mathrm{CaCl}$ low temperature fluid dominant with a wide range of salinity. The second solution is high temperature and salinity Fe-Mg-Na chloride solution. Different fractures in the granite acted as good channels for the hydrothermal fluids that leached uranium from its bearing minerals disseminated all over the host granite and redeposited them in the alteration zones.

\section{Conclusions}

1) The alkali feldspar granite of Gabal El Atawi is post orogenic granite originated from calc-alkaline magma in extensional suite. It is developed in within plate tectonic setting and has $\mathrm{A}_{2}$-type character which generated from apparent crustal source.

2) The petrographic, geochemical and radioactive characteristics of El Atawi granite meet and fulfill the requirements of being fertile granite and it can be considered as promising uraniferous granite.

3) Microthermometric fluid inclusion studies of the altered granite elucidated two different solutions acting on the host granitic pluton. The first is $\mathrm{NaCl}-$ $\mathrm{CaCl}$ low temperature fluid with a wide range of salinity. The second is high temperature and salinity Fe-Mg-Na chloride solution. Different fractures in 
the granite acted as good channels for the hydrothermal fluids that leached uranium from its bearing minerals disseminated all over the host granite and redeposited it in the alteration zones.

\section{References}

[1] Stern, R.J. and Gottfried, D. (1986) Petrogenesis of the Late Precambrian (575-600 Ma) Bimodal Suite in Northeast Africa. Contributions to Mineralogy and Petrology, 24, 492-501. https://doi.org/10.1007/BF00374431

[2] Hassan M.A. and Hashad A.H. (1990) Precambrian of Egypt. In: Said, R., Ed., The Geology of Egypt, Rotterdam, Balkama, 201-245.

[3] Stern R.J. (1979) Late Precambrian Ensimatic Volcanism in the Central Eastern Desert of Egypt. PhD Thesis, University of California, San Diego.

[4] Hussein, A.A., Ali, M.M. and El-Ramlv, M.F. (1982) A Proposed New Classification of the Granites of Egypt. Journal of Volcanology and Geothermal Research, 14, 187-198. https://doi.org/10.1016/0377-0273(82)90048-8

[5] Noweir, A.M., Sewifi, B.M. and Abu El-EIa, A. (1990) Geology, Petrography, Geochemistry and Petrogenesis of the Egyptian Younger Granites. Qatar University Science Bulletin, 10, 363-393.

[6] El-Sayed, M.M. (1998) Tectonic Setting and Petrogenesis of the Kadabora Pluton: A Late Proterozic Anorogenic A-Type Younger Granitoids. Chemie der Erde, 58, 38-63.

[7] Drysdall, A.R., Jackson, N.J., Ramsay, C.R., Douch, C.J. and Hackett, A.D. (1984) Rare Element Mineralization Related to Precambrian Alkali Granites in the Northwest Arabian Shield. Economic Geology, 79, 1366-1377.

https://doi.org/10.2113/gsecongeo.79.6.1366

[8] Küster D. (2009) Granitoid-Hosted Ta Mineralization in the Arabian-Nubian Shield: Ore Deposit Types, Tectono-Metallogenetic Setting and Petrogenetic Framework. Ore Geology Reviews, 35, 68-86. https://doi.org/10.1016/j.oregeorev.2008.09.008

[9] Johnson, P.R., Andresen, A., Collins, A.S., Fowler, A.R., Fritz, H., Ghebrab, W., Kusky, T. and Stern, R.J. (2011) Late Cryogenian-Ediacaran History of the Arabian-Nubian Shield: A Review of Depositional, Plutonic, Structural, and Tectonic Event in the Closing Stages of the Northern East African Orogen. Journal of African Earth Sciences, 61, 167-232. https://doi.org/10.1016/j.jafrearsci.2011.07.003

[10] Hashad, A.H., Sayyah, T.A., El Kholy, S.B. and Yossef, A. (1972) Rb/Sr Isotopic Age Determination of Some Basement Egyptian Granites. Egyptian Journal of Geology, 16, 269-281.

[11] El Manharawy, M.S. (1977) Geochronological Investigation of Some Basement Rocks in Central Eastern Desert, Egypt between Latitudes 25 and 26 N. PhD Thesis, Faculty of Science, University of Cairo, Cairo.

[12] Meneisy, M.Y. and Lenz, H. (1982) Isotopic Ages of Some Egyptian Granites. Annals of the Geological Survey of Egypt, 12, 7-14.

[13] Sabet, A.H., Shemelv, D. and Bordonosov, V. (1975) On the Result of Prospecting Work for Rare and Non-Ferrous Metals and Gold in the Area of Wadis Umm Gheig, Sitra, El Dabbh and Abu tundub. Internal Report, Geol. Surv., Cairo.

[14] Yonan, A.A. (1990) Mineralogical, Petrochemical and Geochemical Studies on Granites Hosting Fluorite Mineralizations in the Eastern Desert of Egypt. Unpubl. PhD Thesis, Geol. Dept., Fac. Sci., Ain Shams Univ., Cairo.

[15] Fasfous, B.R., El Nashar, E.R. and Yonan, A.A. (1992) Chemical and Statistical Parameters for Some Granites and Fluorite Bearing Granites, Eastern Desert, Egypt. 
Egyptian Journal of Geology, 36, 209-232.

[16] Obeid, M.A. (1996) Geological and Geochemical Studies and Ore Potentialities of the Gabal El-Atawi Area, Eastern Desert, Egypt. PhD Thesis, Alexandria Univ., Alexandria, $254 \mathrm{p}$.

[17] Sadek, A.A. (2007) Geology, Geochemistry and Radioactivity of Wadi Fahm Area with Special Emphasis on Granitic Rocks, Central Eastern Desert, Egypt. MSc Thesis, Geol. Dept., Fac. Sci., Cairo Univ., Cairo.

[18] Salman, Y.S.B. (2014) Geochemical Prospecting for Radioactive Mineralization at G Um Naggat-G Atawy Area, Central Eastern Desert, Egypt. PhD Thesis, Menoufiya Univ., Al Minufya.

[19] Fawzy, K.M. (2016) The Genesis of Fluorite Veins in Gabal El Atawi Granite, Central Eastern Desert, Egypt: Application of Fluid Inclusions Technique. Journal of African Earth Sciences, In Press.

[20] Khawasik, S.M. (1968) Geology of Radioactive Localities of Abu Garadi Area, Eastern Desert. MSc Thesis, Ain Shams Univ., Cairo, 157 p.

[21] Attawyia, M.Y. (1978) Geochemical Studies on Some Radioactive Mineralization in Central Eastern Desert, Egypt. PhD Thesis, Ain Shams Univ., Cairo, 224.

[22] Al Anwar, M. (1998) Comparative Studies of the Geology, Mineralogy and Geochemistry of Some U-Mineralization in the Eastern Desert, Egypt. PhD Thesis, South Valley Univ. Aswan, 288 p.

[23] Brown, P.E. (1989) FLINCOR: A Microcomputer Program for the Reduction and Investigation of Fluid Inclusion Data. American Mineralogist, 74, 1390-1393.

[24] Fenn, P.M. (1986) On the Origin of Graphic Granite. American Mineralogist, 71, 325-330.

[25] Katzir, Y., Litvinosky, B.A., Jahn, B.M., Zanvilevich, A.N., Valley, J.W., Pelly, I. and Shimshilavilli, E. (2007) Petrogenesis of A-Type Granites and Origin of Vertical Zoning in Katharina Pluton, Gebel Mousa (Mt Moses) Area, Sinai, Egypt. Lithos, 95, 208-228. https://doi.org/10.1016/j.lithos.2006.07.013

[26] Taylor, S.R. and Mc Lennan, S.M. (1985) The Continental Crust: Its Composition and Evolution. Blackwell, Hoboken, 312.

[27] Mahdy, N.M. (2011) Mineralogical Studies and Mineral Chemistry of Some Radioactive Mineralizations in Gabal Gattar Area, Northern Eastern Desert, Egypt. MSc Thesis. Ain Shams Univ., Cairo.

[28] Mahdy, N.M., Shalaby, M.H., Helmy, H.M., Osman, A.F., El Sawey, E.H. and Abu Zeid, E.K. (2014) Trace and REE Element Geochemistry of Fluorite and Its Relation to Uranium Mineralizations, Gabal Gattar Area, Northern Eastern Desert, Egypt. Arabian Journal of Geosciences, 7, 2573-2589.

[29] Shalaby, M.H., Abu Zeid, E.K. and Mahdy, N.M. (2014) On the Petrogenesis and Evolution of Urich Granite: Insights from Mineral Chemistry Studies of Gattar Granite, North Eastern Desert, Egypt. Arabian Journal of Geosciences, 8, 3587. https://doi.org/10.1007/s12517-014-1573-x

[30] Cox, K.G., Bell, I.D. and Pankhurst, R.J. (1979) The Interpretation of Igneous Rocks. Springer, Berlin. https://doi.org/10.1007/978-94-017-3373-1

[31] De La Roche, H., Leterrier, J., Grandclade, P. and Marchal, M. (1980) A Classification of Volcanic and Plutonic Rocks Using RI-R2 Diagram and Major Element Analyses: Its Relationship with Current Nomenclature. Chemical Geology, 29, 183-210. https://doi.org/10.1016/0009-2541(80)90020-0

[32] Middlemost, E.A.K. (1985) Magma and Magmatic Rocks. Longman Group Limited, Essex. 
[33] Streckeisen A. (1976) Classification of Common Igneous Rocks by Mean of Their Chemical Composition. A Provisional Attempt. Neues Jahrbuch für Mineralogie, Monatshefte, 1, 1-15.

[34] Irvine, T.N. and Baragar, W.R.A. (1971) A Guide to the Chemical Composition of the Common Volcanic Rocks. Canadian Journal of Earth Sciences, 8, 523-548. https://doi.org/10.1139/e71-055

[35] Petro, W.L., Vogel, T.A. and Wilband, J.T. (1979) Major Element Chemistry of Plutonic Rock Suites from Compressional and Extensional Plate Boundaries. Chemical Geology, 26, 217-235. https://doi.org/10.1016/0009-2541(79)90047-0

[36] Whalen, J.B., Curri, K.L. and Chappell B.W. (1987) A-Type Granites Geochemical Characteristics, Discrimination and Petrogenesis. Contributions to Mineralogy and Petrology, 95, 407-419. https://doi.org/10.1007/BF00402202

[37] Frost, B.R., Barnes, C.G., Collins, W.J., Arculus, R.J., Ellis, D.J. and Frost, C.D. (2001) A Geochemical Classification for Granitic Rocks. Journal of Petrology, 47, 2033-2048. https://doi.org/10.1093/petrology/42.11.2033

[38] Eby, G.N. (1992) Chemical Subdivision of the A-Type Granitoids: Petrogenetic and Tectonic Implications. Geology, 20, 641-644. https://doi.org/10.1130/0091-7613(1992)020<0641:CSOTAT>2.3.CO;2

[39] Dall'Agnol, R. and de Oliveira, D.C. (2007) Oxidized, Magnetite-Series, RapakiviType Granites of Carajás, Brazil: Implications for Classification and Petrogenesis of A-Type Granites. Lithos, 93, 215-233. https://doi.org/10.1016/j.lithos.2006.03.065

[40] Pearce, J.A., Harris, N.B.W. and Tindle, A.G. (1984) Trace Element Discrimination Diagrams for the Tectonic Interpretation of Granitic Rocks. Journal of Petrology, 25, 956-983.

[41] Harris, N.B.W., Pearce, J.A. and Tendle, A.G. (1986) Geochemical Characteristics of Collision-Zone Magmatism. In: Coward, M.P. and Ries, A.C., Eds., Collision Tectonics, Spec. Publ. Geol. Soc. 19, London, 67-81. https://doi.org/10.1144/GSL.SP.1986.019.01.04

[42] Grebennikove, A.V. (2014) A-Type Granites and Related Rocks: Petrogenesis and Classification. Russian Geology and Geophysics, 55, 1354-1366.

[43] Pearce, J.A. (1996) Sources and Settings of Granitic Rocks. Episode, 19, 120-125.

[44] Maniar, P.D. and Piccoli, P. (1989) Tectonic Dscrimination of Granitoids. Geological Society of America Bulletin, 101, 635-643. https://doi.org/10.1130/0016-7606(1989)101<0635:TDOG >2.3.CO;2

[45] Batchelor, R.A. and Bowden, P. (1985) Petrogenetic Interpretation of Granitoid Rock Series Using Multicationic Parameters. Chemical Geology, 48, 43-55. https://doi.org/10.1016/0009-2541(85)90034-8

[46] Bonin, B. (2007) A-Type Granites and Related Rocks: Evolution of Concept, Problems and Prospects. Lithos, 97, 1-29. https://doi.org/10.1016/j.lithos.2006.12.007

[47] Panahi, A., Young, G.M. and Rainibird, R.H. (2000) Behavior of Major and Trace Elements (Including REE) during Paleoproterozoic Pedogenesis and Digenetic Alteration of an Archean Granite near Nile Marie, Quebec, Canada. Geochimica et Cosmochimica Acta, 4, 2199-2220. https://doi.org/10.1016/S0016-7037(99)00420-2

[48] Wilke, M. and Behrens, H. (1999) The Dependence of the Partitioning of Iron and Europium between Plagioclase and Hydrous Tonalite Melt on Oxygen Fugacity. Contributions to Mineralogy and Petrology, 137, 102-114. https://doi.org/10.1007/s004100050585

[49] Henderson, P. (1996) Rare Earth Elements, Introduction and Review. In: Jones, A.P., Wall, F. and Williams, C.T., Eds., Rare Earth Minerals. Chemistery, Origin 
and Deposits, the Mineralogical Society Series, Chapman and Hall, New York, 1-19.

[50] Schnetzler, C.C. and Philopotts, J.A. (1970) Partition Coefficients of Rare Earth Elements between Igneous Matrix Material and Rock-Forming Mineral Phenocrysts-II. Geochimica et Cosmochimica Acta, 34, 331-340. https://doi.org/10.1016/0016-7037(70)90110-9

[51] Gill, R. (1996) Chemical Fundamentals of Geology. Harper Collins Academic Publishers, London, $291 \mathrm{p}$.

[52] Möller, P. and Muecke, G.K. (1984) Significance of Europium Anomalies in Silicate Melts and Crystal-Melt Eqilibria: A Re-Evaluation. Contributions to Mineralogy and Petrology, 87, 242-250. https://doi.org/10.1007/BF00373057

[53] Muecke, G.K. and Clarke, D.B. (1981) Geochemical Evolution of the South Mountain Batholith, Nova Scotia: Rare-Earth Element Evidence. Canadian Mineralogist, 19, 133-145.

[54] Irber, W. (1999) The Lanthanide Tetrad Effect and Its Correlation with K/Rb, $\mathrm{Eu} / \mathrm{Eu}^{*}, \mathrm{Sr} / \mathrm{Eu}, \mathrm{Y} / \mathrm{Ho}$ and $\mathrm{Zr} / \mathrm{Hf}$ of Evolving Peraluninous Granite Suites. Geochimica et Cosmochimica Acta, 63, 489-508. https://doi.org/10.1016/S0016-7037(99)00027-7

[55] Jahn, B.M., Wu, F.Y., Cabdevila, R., Martineau, F., Zhao, Z.H. and Wang, Y.X. (2001) Highly Evolved Juvenile Granites with Tetrad REE Patterns: The Woduhe and Baerzhe Granites from the Great Xing'an Mountains NE China. Lithos, 59, 171-198. https://doi.org/10.1016/S0024-4937(01)00066-4

[56] Monecke, T., Kempe, U., Monecke, J., Sala, M. and Wolf, D. (2002) Tetrad Effect in Rare Earth Element Distribution Patterns: A Method of Quantification with Application to Rock and Mineral Samples from Granite-Related Rare Metal Deposits. Geochimica Et Cosmochemicha Acta, 66, 1185-1196.

[57] Johannes, W. and Holtz, F. (1996) Petrogenesis and Experimental Petrology of Granitic Rocks. Minerals and Rocks 22, Springer, Berlin, 115-275.

https://doi.org/10.1007/978-3-642-61049-3

[58] Anders, E. and Grevesse, N. (1989) The Abundances of the Elements: Meteoritic and Solar. Geochimica et Cosmochimica Acta, 53, 197-214. https://doi.org/10.1016/0016-7037(89)90286-X

[59] Taylor, S.R. (1965) The Application of Trace Element Data to Problems in Petrology. Physics and Chemistry of the Earth, 6, 133-213. https://doi.org/10.1016/0079-1946(65)90014-5

[60] Clarke, D.B. (1992) The Mineralogy of Peraluminous Granites: A Review. Canadian Mineralogist, 19, 3-17.

[61] Sheare, C.K., Papike, J.J. and Laul, J.C. (1985) Chemistry of Potassium Feldspars from Three Zoned Pegmatites, Black Hills, South Dakota: Implications Concerning Pegmatite Evolution. Geochimica et Cosmochimica Acta, 49, 663-673. https://doi.org/10.1016/0016-7037(85)90161-9

[62] Shaw, D.M. (1968) A Review of K-Rb Fractionation Trends by Covariance Analyses. Geochimica et Cosmochimica Acta, 32, 573-601. https://doi.org/10.1016/0016-7037(68)90050-1

[63] Mason, B. (1966) Principals of Geochemistry. 3rd Edition, John Wiley \& Sons, New York, 610.

[64] Condie, K.C. (1973) Archean Magmatism and Crustal Thickening. Geological Society of America Bulletin, 84, 2981-2991. https://doi.org/10.1130/0016-7606(1973)84<2981:AMACT>2.0.CO;2

[65] Sun, S.S. and Nesbitt, R.W. (1978) Petrogenesis of Archean Ultrabasic and Basic 
Volcanics: Evidence from Rare Earth Elements. Contributions to Mineralogy and Petrology, 65, 301-328. https://doi.org/10.1007/BF00375516

[66] Bau, M. (1996) Controls on the Fractionation of Isovalent Trace Elements in Magmatic and Aqueous Systems: Evidence from Y/Ho, Zr/Hf and Lanthanide Tetrad Effect. Contributions to Mineralogy and Petrology, 123, 323-333. https://doi.org/10.1007/s004100050159

[67] Bau, M. and Dulski, P. (1995) Comparative Study of Ytrium and Rare-Earth Elements Behaviors in Fluorine-Rich Hydrothermal Fluids. Contributions to Mineralogy and Petrology, 119, 213-223. https://doi.org/10.1007/BF00307282

[68] Erlank, A.J., Marchant, J.W., Cardoso, M.P. and Ahrens, L.H. (1978) Zirconium. In: Wedepohl, K.H., Ed., Handbook of Geochemistry, Vol. 11/4, Springer, Berlin, 40.

[69] Turekian, K.K. and Wedepohl, K.H. (1961) Distribution of Elements in Some Major Units of Earth's Crust. Geological Society of America Bulletin, 72, 175-190. https://doi.org/10.1130/0016-7606(1961)72[175:DOTEIS]2.0.CO;2

[70] Clark, S.P., Petrman, Z.E. and Heier, K.S. (1966) Abundance of Uranium, Thorium and Potassium, In: Clark, S.P., Ed., Handbook of Physical Constraints, Geol. Soc. Am. Mem. 97, Geological Society of America, New York, 521-541. https://doi.org/10.1130/MEM97-p521

[71] Adams, J.A.S., Osmond, Y.K. and Rogers, J.J.W. (1969) The Geochemistry of Thorium and Uranium, Physics and Chemistry of the Earth. 3rd Edition, Pergamon Press, London.

[72] Darnely, A.G. (1982) "Hot Granites” Some General Remarks. In: Maurice, Y.J., Ed., Uranium in Granites, Geol. Surv. Canada, Paper No. 81-23, 1-10.

[73] Rogers, J.J.W. and Adams, J.A.S. (1969) Uranium and Thorium, In: Wedepohl, K.H., Ed., Handbook of Geochemistry, Vol. 113, Springer, Berlin, 92-B-1 to 92-0-8 and $90-\mathrm{Bb}-1$ to $90-00-5$.

[74] Boyle, R.W. (1982) Geochemical Prospecting for Thorium and Uranium Deposits. Developments in Economic Geology 16, Elsevier, Amsterdam, 189.

[75] Cuney, M. (1984) Les Methods des Prospection de 1'uranium. Nuclear Energy Agency of the OECD, Paris, 277-292.

[76] Cambon, A.R. (1994) Uranium Deposits in Granitic Rocks. Notes on the National Training Course on Uranium Geology and Exploration, Organized by IAEA and NMA, Cairo.

[77] Roedder, E. (1984) Fluid Inclusions. In: Ribbe, P.H., Ed., Reviews in Mineralogy, Mineralogical Society of America, Washington DC, Vol. 12, 337-360.

[78] Shalaby, M.H. (1995) New Occurrence of Uranium Mineralization G-VII, Gabal Gattar Uranium Prospect, North Eastern Desert, Egypt. Bulletin Faculty of Science, Alexandria University, Alexandria, 447-460.

[79] Moharam, A.F. and Dardir, A.M. (2000) Uranium Distribution in the Mineral Constituents of Ain Rowayshed-Abu Samyuk Younger Granites and the Associated Pegmatites North Eastern Desert, Egypt. 5th Arab Conference on the Peaceful Uses of Atomic Energy, Beirut, 13-17 November 2000, (Abstract).

[80] Bakhit, F.S., Hussein, H.A. and Ali, M.M. (1999) Geotectonics and Characteristic Features of Fertile and Non-Fertile Younger Granites, Eastern Desert, Egypt. In: Sinha, A.K., Ed., Basement Tectonics 13, Springer, Berlin, 1-24. https://doi.org/10.1007/978-94-011-4800-9 1

[81] Assaf, H.S., Mahdy, M.A. and El Afandy, A. (1997) Egyptian Younger Granites: An Approach to Define Parameters Favoring Formation of Uranium Deposits. 3rd Conference of Geochemistry, Alexandria, 3-4 September 1997, 409-420. 
Submit or recommend next manuscript to SCIRP and we will provide best service for you:

Accepting pre-submission inquiries through Email, Facebook, LinkedIn, Twitter, etc. A wide selection of journals (inclusive of 9 subjects, more than 200 journals)

Providing 24-hour high-quality service

User-friendly online submission system

Fair and swift peer-review system

Efficient typesetting and proofreading procedure

Display of the result of downloads and visits, as well as the number of cited articles Maximum dissemination of your research work

Submit your manuscript at: http://papersubmission.scirp.org/

Or contact ojg@scirp.org 